\title{
Tectonic context of moderate to large historical earthquakes in the Lesser Antilles and mechanical coupling with volcanoes
}

\author{
Nathalie Feuillet, ${ }^{1}$ François Beauducel, ${ }^{1}$ and Paul Tapponnier ${ }^{2}$ \\ Received 13 April 2011; accepted 11 July 2011; published 15 October 2011.
}

[1] The oblique convergence between North American and Caribbean plates is accommodated in a bookshelf faulting manner by active, oblique-normal faults in the northern part of the Lesser Antilles arc. In the last 20 years, two $M>6$ earthquakes occurred along a large, arc parallel, en echelon fault system, the 16 March 1985 in Redonda and 21 November 2004 in Les Saintes. A better understanding of active faulting in this region permit us to review the location and magnitude of historical earthquakes by using a regional seismic attenuation law. Several others moderate earthquakes may have occurred along the en echelon fault system implying a strong seismic hazard along the arc. These faults control the effusion of volcanic products and some earthquakes seem to be correlated in time with volcanic unrest. Shallow earthquakes on intraplate faults induced normal stress and pressure changes around neighboring volcano and may have triggered volcanic activity. The Redonda earthquake could have initiated the 1995 eruption of Montserrat's Soufrière Hills by compressing its plumbing system. Conversely, pressure changes under the volcano increased Coulomb stress changes and brought some faults closer to failure, promoting seismicity. We also discuss the magnitude of the largest 11 January 1839 and 8 February 1843 megathrust interplate earthquakes. We calculate that they have increased the stress on some overriding intraplate faults and the extensional strain beneath several volcanoes. This may explain an increase of volcanic and seismic activity in the second half of the 19th century culminating with the devastating, 1902 Mount Pelée eruption.

Citation: Feuillet, N., F. Beauducel, and P. Tapponnier (2011), Tectonic context of moderate to large historical earthquakes in the Lesser Antilles and mechanical coupling with volcanoes, J. Geophys. Res., 116, B10308, doi:10.1029/2011JB008443.

\section{Introduction}

[2] In the Lesser Antilles, the most important active faults were identified and mapped offshore and onshore, at several scales, by combining high-resolution marine data and observations and measurements in the field [Feuillet, 2000; Feuillet et al., 2002, 2004a, 2010; Leclerc, 2009]. In the northern part of the arc, they are normal or oblique and form two distinct sets (Figure 1). Faults belonging to the first set bound arc-perpendicular graben or half graben that disrupt the fore-arc reef platforms of Guadeloupe, Antigua-Barbuda, and St. Martin-St. Barthelemy. The second fault set is a large right-stepping en echelon system that appears to accommodate a transtensionnal motion along the volcanic arc between Saba, the northernmost volcano, and Martinique. At plate scale, the arc-perpendicular fore-arc graben and inner-arc en echelon system are connected, forming a sinistral horsetail east of the tip of the left-lateral Puerto Rico fault zone that

\footnotetext{
${ }^{1}$ Institut de Physique du Globe de Paris, UMR 7154 CNRS, Sorbonne Paris Cité, Paris, France.

${ }^{2}$ Earth Observatory of Singapore, Nanyang Technological University, Singapore.

Copyright 2011 by the American Geophysical Union. 0148-0227/11/2011JB008443
}

takes up the trench-parallel component of convergence between the North American and Caribbean plates west of the Anegada passage (Figure 1, inset). Considering the new Caribbean North American Euler vector of Lopez et al. [2006], the trench parallel component of shear increases northwestward with the curvature of the northern Caribbean plate edge, from $4 \mathrm{~mm} / \mathrm{yr}$ in Martinique to $17 \mathrm{~mm} / \mathrm{yr}$ in St. Martin (Figure 1, inset), suggesting a total of a few millimeters per year across the entire fault system [Feuillet et al., 2010].

[3] Few hundred earthquakes are recorded each year by the local seismic network in the Lesser Antilles arc and several damaging ones have occurred during the historical period. The intraplate faults are responsible for a part of the shallow seismicity in the arc implying a strong seismic hazard in addition to that related to large subduction earthquakes. Two $M \geq 6$ earthquakes have occurred along the en echelon system in the last 20 years, on 16 March 1985 in Redonda, close to Nevis, and on 21 November 2004 near Les Saintes in Guadeloupe. The 21 November 2004 earthquake ruptured a $\mathrm{N} 140^{\circ} \mathrm{E}$ striking normal fault (Roseau fault) offshore between Dominica and Les Saintes identified as active from high-resolution bathymetric data a few years before [Feuillet et al., 2011; Bazin et al., 2010]. 
Several other large interplate and moderate intraplate earthquakes were reported in the arc during the historical period. Information (epicenter location, distribution of intensities, damage) about these events is scattered in several reports, catalogs, and papers, some in French. We first collected and summarized all information available for the larger earthquakes reported. In the light of the improved tectonic understanding brought by the study of active faulting mapping and most recent earthquakes in the Lesser Antilles arc, we discuss the origin of these events. We then use a regional seismic attenuation law to verify or tentatively reassess, on the basis of reported intensities, their magnitudes.

[4] That the occurrence of the last 2004-2008 seismic sequence of Les Saintes, close to the Soufrière volcano, might potentially increase volcanic hazard in Guadeloupe prompts us to investigate through statistical analyses and stress models the correlation and two-way mechanical coupling between earthquakes and volcanoes at several space and time scales. By modeling the Coulomb static stress changes induced by volcanic processes, we seek to understand the distribution of early seismicity recorded at the

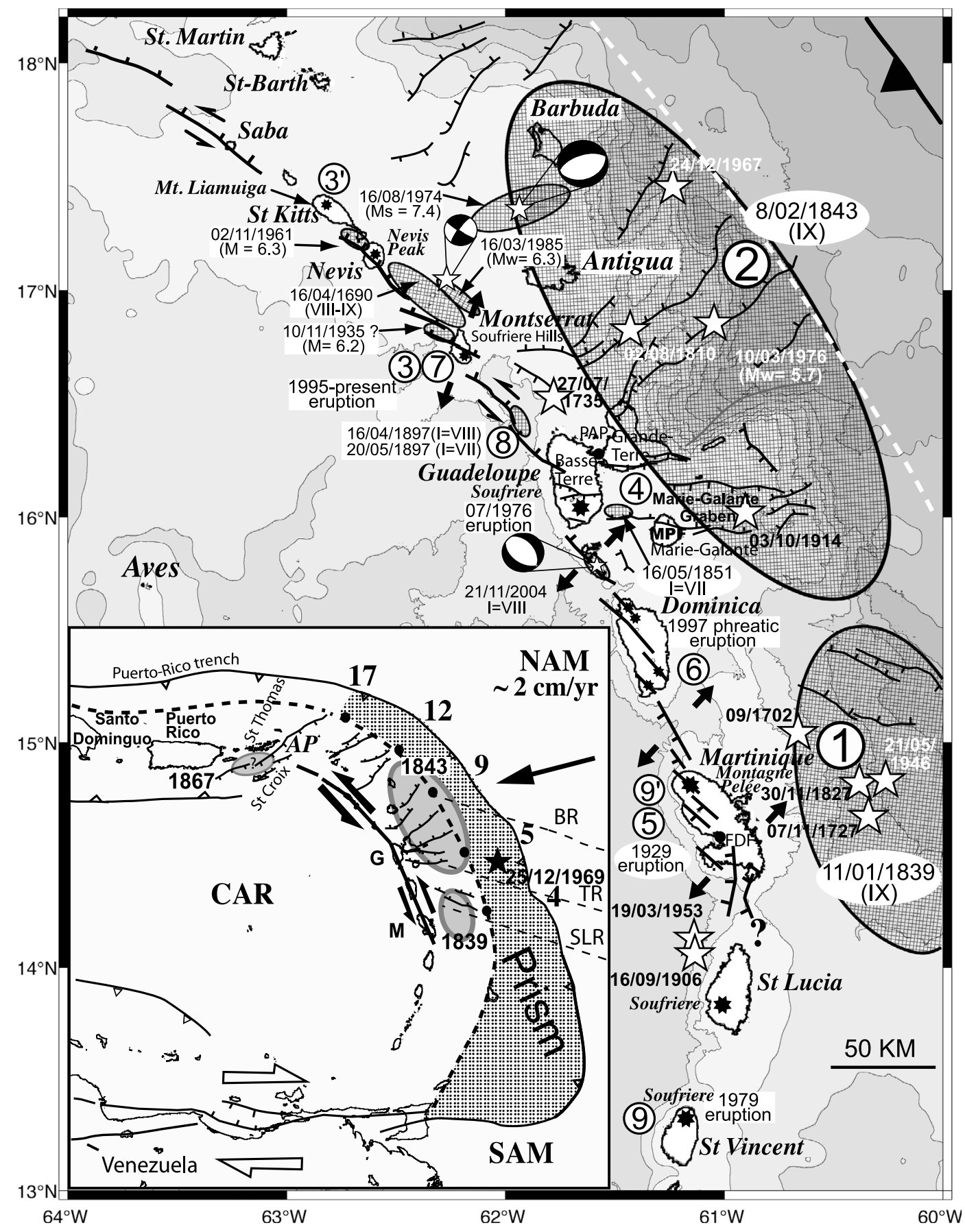

Figure 1 
beginning of Soufrière Hills volcano ongoing eruption in Montserrat.

\section{Lesser Antilles Damaging Historical Earthquakes and Responsible Faults}

[5] Figure 2 summarizes all information (location and intensities) about the Lesser Antilles significant earthquakes collected in several reports and papers [Sainte-Claire Deville, 1843; Perret, 1939; Robson, 1964; Dorel, 1981; Feuillard, 1985; Bernard and Lambert, 1988; Shepherd et al., 2002] and shows the major active faults mapped in the arc [Feuillet, 2000; Feuillet et al., 2002, 2004a, 2010; Leclerc, 2009]. In the following, we discuss case by case the possible origin of these events.

\subsection{Earthquake of 16 April 1690}

[6] The oldest large earthquake reported in the West Indies occurred on April 1690. It caused serious damages in Antigua, St. Kitts, and Nevis. There are conflicting reports about this event. Robson [1964] mentioned that a large earthquake occurred on 5 April and was felt across the entire northern arc, except in Grenadine, with intensities of IX in Antigua, St. Kitts, Nevis, and Guadeloupe. Other earthquakes were reportedly felt on 10 April [Perrey, 1847] and 16 April [Feuillard, 1985]. Feuillard [1985] proposed that the earthquake felt in Guadeloupe occurred on the 16th, instead of the 5th or 10th, and that maximum intensities were VIII, instead of IX, in Antigua, St. Kitts, and Nevis and only VI in Guadeloupe where a large, damaging event was not mentioned in local chronicles. Historical reports mentioned 3-m-wide opened fissures in St. Kitts and several landslides on Nevis peak [Robson, 1964]. This earthquake probably triggered a tsunami, since it was reported that the sea withdrew over a distance of $200 \mathrm{~m}$ in Charleston (western part of Nevis) and returned after $2 \mathrm{~min}$. Overall, the intensities and reported damage are in agreement with a shallow earthquake located between Nevis, Antigua, and Montserrat [Feuillard, 1985]. In this area, several active faults were identified in the bathymetry and seismic reflection profiles; they belongs to the en echelon fault system [Feuillet et al., 2004a, 2010]. The April 1690 earthquake may have ruptured the fault set named Montserrat-Havers and Redonda (Figures 1 and 2a). In this case, the epicenter could have been closer to Montserrat and Nevis (black star in Figure 2a) than previously inferred by Feuillard [1985] (white star in Figure 2a).

\subsection{Earthquake of 11 January 1839}

[7] The 11 January 1839 earthquake destroyed the town of Fort Royal (Fort-de-France) killing several hundred people. The most important damage is reported in Martinique. A maximum intensity of VIII and IX was estimated by Feuillard [1985] and Robson [1964], respectively. The distribution of intensities in other islands (Figure 2b) are in agreement with an epicenter east of Martinique [Dorel, 1981], west of the subducting St. Lucia Ridge, an area of sustained seismic activity with several earthquakes recorded daily (Institut de Physique du Globe de Paris (IPGP) reports, www. ipgp.fr). The 1839 earthquake was probably a megathrust event similar to that of 8 February 1843 described below.

\subsection{Earthquake of 8 February 1843}

[8] "This earthquake was considerably bigger than any other that has happened in this region in historical time" [Shepherd, 1992, p. 1541]. It destroyed the city of Pointe-àPitre and killed more than 1500 people [Sainte-Claire Deville, 1843]. It was associated with hydrological phenomena. Up to $1.5-\mathrm{m}$-high mud fountains were observed across the whole Grande-Terre and along the eastern coast of Basse-Terre. New springs appeared and others dried up or flow rates significantly changed. The water level changed in some wells on Grande-Terre. The earthquake also induced large cliff collapses along the eastern coast of Guadeloupe and several landslides were reported on volcanic domes. It was reported

Figure 1. Active faulting and volcanism in the Lesser Antilles arc. Main earthquakes and eruptions after Bernard and Lambert [1988], Boudon et al. [2005], Feuillard [1985], Hincks et al. [2005], Komorowski et al. [2005], Lindsay [2005], Lindsay et al. [2005], Robertson [2005a, 2005b], Robson et al. [1962], Robson [1964], Simpson [2005], and this study. Focal mechanisms [McCann et al., 1982; Dziewonski et al., 2000]. Active faults in black with ticks from Feuillet [2000], Feuillet et al. [2001, 2002, 2004a, 2010], Leclerc [2009]. Faults in Martinique and in Dominica from N. Feuillet et al. (manuscript in preparation, 2011). Double black arrows indicate local extension. Black arrows indicate the sinistral component of motion along the inner arc faults. Black stars indicate active volcanic centers. Ellipses indicate inferred ruptured area (see text) during moderate to large earthquakes with numbers. White stars with dates indicate epicenters of other $M>6$ earthquakes reported in the arc. (1) Earthquake of 11 January 1839, (2) earthquake of 8 February 1843, (3) 1843 geothermal activity in Upper Gage, (3')1843 eruption of Mt. Liamuiga (St. Kitts), (4) earthquake of 16 May 1851 ( $I_{\max }$ VIII), (5) Mt. Pelée phreatic eruption of 5 August 1851, (6) Desolation Valley phreatic eruption of 4 January 1880, (7) severe seismic activity in Monserrat of $23-$ 27 April 1897, (8) earthquake of 29 April 1897 ( $I_{\max }$ VIII), (9) St. Vincent eruption of 6 May 1902, (9') Mt. Pelée climactic eruption of 8 May 1902. Dates of other older or more recent significant volcanic events and earthquakes are also reported. Bathymetric contours at $1000 \mathrm{~m}$ interval. White dashed line indicates negative gravity anomaly corresponding to the updip contact between the Caribbean and subducting American plates [Westbrook et al., 1988; Bowin, 1976]. Inset is a simplified map showing the link between the en echelon inner arc fault system and the subduction with the trench parallel component of shear increasing from 4 to $17 \mathrm{~mm} / \mathrm{yr}$ between Martinique and St. Martin (black dots with numbers, considering the new Caribbean North American Euler vector of Lopez et al. [2006]). Black line with arrows indicates inner en echelon fault system with slip probably increasing northward. Gray ellipses with dates indicate inferred rupture associated with the three largest earthquakes reported in the arc and the Virgin Islands since the historical period after Bernard and Lambert [1988], Feuillard [1985], Reid and Taber [1920], and this study. Hashed area indicates accretionary prism, where BR is Barracuda ridge, TR is Tiburon ridge, SLR is St. Lucia ridge, G is Guadeloupe, M is Martinique, and AP is Anegada Passage. Black line with triangles indicates accretionary prism frontal thrust. Dashed black line indicates main gravity anomaly. 

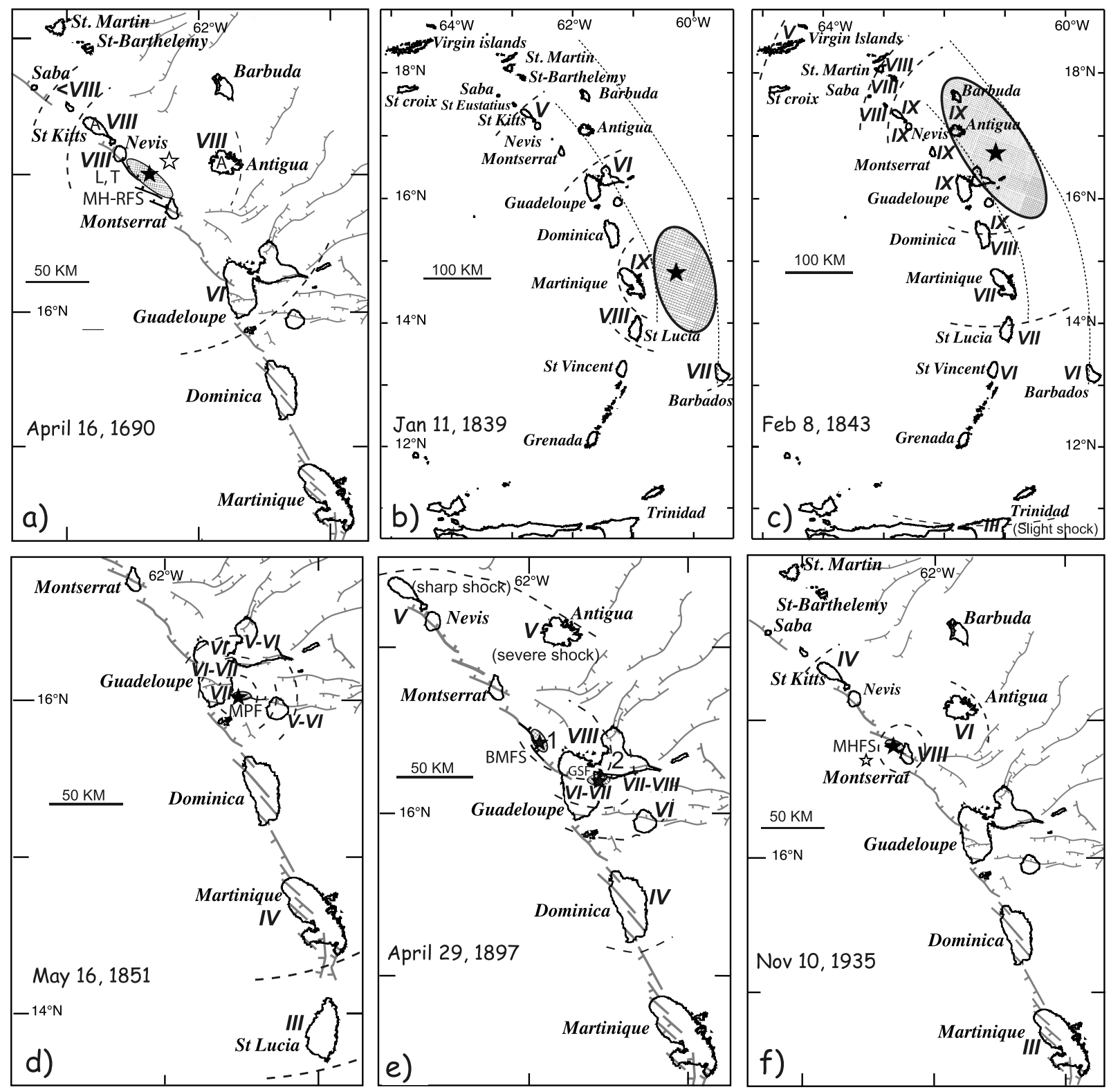

Figure 2. Reported intensities for historical and recent earthquakes. Faults as in Figure 1, in black when possibly responsible for earthquakes. See discussion and references in text. Thick dashed lines indicate approximate isoseists. Dashed areas show the approximate size of the ruptured zones estimated by using the Wells and Coppersmith [1994] relation between rupture length and magnitude. (a) Earthquake of 16 April 1690, where black star indicates epicenter inferred by this study, white star indicates epicenter from Feuillard [1985], MH-RFS is the Montserrat Havers-Redonda fault system, A indicates felt aftershocks, L indicates landslides, T indicates tsunami. (b) Event of 11 January 1839, where black star indicates epicenter from Feuillard [1985]. (c) Event of 8 February 1843, where black star indicates epicenter from Feuillard [1985]. (d) Event of 16 May 1851, where black star indicates epicenter from Bernard and Lambert [1988] and MPF indicates Morne Piton fault. (e) Event of 29 April 1897, where black stars indicate (1) epicenter from Feuillard [1985] $(M \approx 7)$ and (2) epicenter from Bernard and Lambert [1988] $(M=5.5)$, GSF indicates Gosier fault, and BMFS indicates Bouillante-Montserrat fault system. (f) Event of 10 November 1935, where white star indicates epicenter from Gutenberg and Richter [1954], black star indicates epicenter inferred in this study, and MHFS is Montserrat-Havers fault system. (g) Events of 29 December 1950 and 2 November 1961, where black star indicates epicenter from Robson et al. [1962] and SK-NFS is St. Kitts-Nevis fault system. (h) Event of 8 October $1974\left(M_{w}=7.4\right)$, where black star indicates epicenter from McCann et al. [1982] and NAF is North Antigua fault. (i) Event of 16 March 1985 $\left(M_{w}=6.3\right)$, where black star indicates epicenter from Girardin et al. [1991] and RFS is Redonda fault system. (j) Event of 21 November $2004\left(M_{w}=6.3\right)$, where black star indicates epicenter from Bazin et al. [2010] and RF is Roseau fault. 

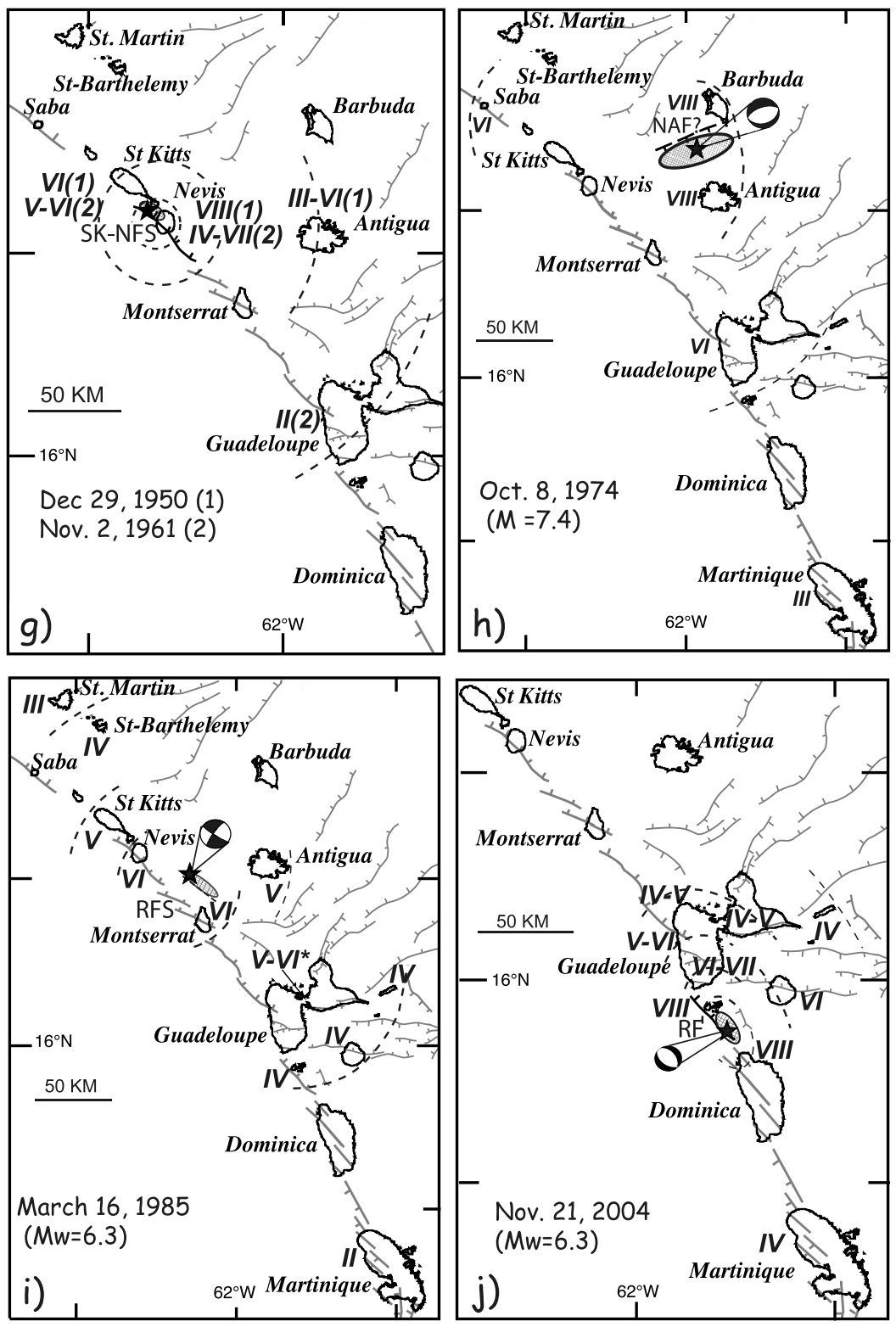

Figure 2. (continued)

that the Pointe-à-Pitre wharfs subsided by $30 \mathrm{~cm}$ [Feuillard, 1985; Bernard and Lambert, 1988]. Small islands also subsided in the bay of Pointe-à-Pitre. By contrast, the eastern coast of Grande-Terre was apparently uplifted by few tens of centimeters [Sainte-Claire Deville, 1843; Bernard and Lambert, 1988]. The earthquake was followed by a large number of aftershocks felt in Guadeloupe with intensities ranging between III and VII. Most of them occurred in the first 8 months following the main shock [Sainte-Claire Deville, 1843], the largest one (intensity VII) on 11 May 1843. The 8 February 1843 earthquake was probably a megathrust earthquake, rupturing the deeper part of the North America/Caribbean plate interface between Grande-Terre and
Antigua. They are conflicting reports concerning this event. Robson [1964] and Shepherd [1992] estimated intensities of IX in a large part of the arc between Dominica and Nevis implying a 300-km-long fault segment and a magnitude of 8 to 8.5 (Figure 2c). Following Bernard and Lambert [1988], no significant tsunami was promoted by the 1843 earthquake, whereas Shepherd [1992] mentioned several observations of tsunami reported in Antigua and Nevis. On the basis of chronicles and particularly the detailed reports of the geologist Sainte-Claire Deville [1843], Bernard and Lambert [1988] reevaluated the intensities in all islands of the Guadeloupe archipelago. They inferred that the earthquake reached the intensity IX only in some parts of Guadeloupe 
Table 1. Macroseismic Intensities Reported by Different Authors for 8 February 1843 Earthquake

\begin{tabular}{|c|c|c|c|}
\hline Island & $\begin{array}{l}\text { Robson } \\
{[1964]}\end{array}$ & $\begin{array}{c}\text { Bernard and } \\
\text { Lambert [1988] }\end{array}$ & $\begin{array}{c}\text { Shepherd } \\
\text { [1992] }\end{array}$ \\
\hline St. Thomas & IV & & \\
\hline Tortola & V & & \\
\hline St. Martin & VIII & & VIII ? \\
\hline St. Barthelemy & VIII & & VIII ? \\
\hline Saba & & IX ? & \\
\hline Barbuda & & IX? & \\
\hline St. Eustatius & VIII & & IX \\
\hline St. Kitts & IX & VII & IX \\
\hline Nevis & IX & VIII & IX \\
\hline Antigua & IX & IX & IX \\
\hline Montserrat & IX & VIII & IX \\
\hline Guadeloupe & IX & $\begin{array}{l}\text { IX (Pointe-à-Pitre, } \\
\text { Anse-Bertrand, } \\
\text { Goyave, Le Gosier, } \\
\text { Le Moule, } \\
\text { Petit-Bourg, } \\
\text { Petit-Canal, } \\
\text { Port-Louis, } \\
\text { Sainte-Anne, } \\
\text { Sainte-Rose, } \\
\text { Saint-François, } \\
\text { Vieux-Habitants) } \\
\text { VIII (Basse-Terre, } \\
\text { Bouillante, } \\
\text { Capesterre-M/G, } \\
\text { Grand-Bourg, } \\
\text { Les Saintes, } \\
\text { La Désirade) }\end{array}$ & IX \\
\hline Martinique & VII & VI, VII & \\
\hline \multirow[t]{2}{*}{ Dominica } & IX (North) & VIII (North) & IX (North) \\
\hline & VIII (Roseau) & VII (Roseau) & VIII (Roseau) \\
\hline St. Lucia & VII & V & VII \\
\hline St. Vincent & & & VI \\
\hline Barbados & & VI & \\
\hline
\end{tabular}

(Grande-Terre and northern Basse-Terre) and Antigua and estimated a magnitude of 7.5 to 8 . We reported all available intensities in Table 1.

\subsection{Earthquake of 16 May 1851}

[9] A few years later, the 16 May 1851 struck the Guadeloupe archipelago with a maximum intensity of VII in southern Basse-Terre (Figure 2d). Following Feuillard [1985] and Bernard and Lambert [1988], the epicentral area was located offshore at shallow depth between MarieGalante and Basse-Terre. In this area the seafloor is cut by the several tens kilometers long E-W striking Morne-Piton normal fault system (MPF) that crosses the islands of BasseTerre and Marie-Galante [Feuillet, 2000; Feuillet et al., 2004a]. This event probably ruptured a segment of the Morne-Piton fault system between the two islands (MPF on Figure 1).

\subsection{Earthquake of 29 April 1897}

[10] The 29 April 1897 earthquake was felt with a maximum intensity of VIII in Guadeloupe (Figure 2e). It caused serious damage in Pointe-à-Pitre, killing four people. It was followed by a second, somewhat smaller event on 20 May 1897. Unlike Bernard and Lambert [1988] who located the 29 April 1897 earthquake just west of Pointe-à-Pitre and calculated a magnitude 5.5 for this event, Feuillard [1985] inferred a hypocenter between Basse-Terre and Montserrat and a magnitude 7. The epicenter proposed by Bernard and Lambert [1988] would be in agreement with a rupture along the E-W striking Gosier normal fault (GSF) that crosscuts the southern shore of Grande-Terre and the Pointe-à-Pitre Town [Feuillet et al., 2002]. The epicenter proposed by Feuillard [1985] rather suggests a rupture along the southern part of the Bouillante-Montserrat fault segments (BMFS) between the 1690/1985 and 2004 earthquakes.

\subsection{Earthquake of 10 November 1935}

[11] The $M=6.2,10$ November 1935 earthquake occurred near Montserrat $\left(16.7^{\circ} \mathrm{N} ; 62.5^{\circ} \mathrm{W}\right.$ [Gutenberg and Richter, 1954]). It was felt with intensities of VIII in Montserrat, VI in Antigua, IV in St. Kitts [Robson, 1964], and III in Martinique [Feuillard, 1985] (Figure 2f). A hypocentral depth of $100 \mathrm{~km}$, as proposed by Gutenberg and Richter [1954], suggests an intermediate intraplate earthquake in the North American slab. A depth of $150 \mathrm{~km}$ would be however more compatible with the slab geometry beneath Montserrat [Feuillet et al., 2002]. This event could have been much more shallow and may have occurred along the NW-SE striking north dipping Montserrat-Havers fault system (MHFS) identified and mapped northeast of Montserrat [Feuillet et al., 2010]. In this case, the epicenter (black star on Figure 2f) would have been located a few kilometers northeastward than previously proposed by Gutenberg and Richter [1954] (white star in Figure 2f). In the next section, we discuss this hypothesis on the basis of regional attenuation models.

\subsection{Earthquakes of 29 December 1950 and 2 November 1961}

[12] Between 27 December 1950 and May 1951, the islands of Nevis and St. Kitts were struck by a series of earthquakes with two severe shocks on 29 and 31 December. More than 150 earthquakes occurred in January 1951 and minor renewals of activity occurred in March and May 1951 [Willmore, 1952]. The 29 December 1950 shock was felt with a intensity of VIII in Nevis, VI in St. Kitts (BasseTerre), and III to V in Antigua [Willmore, 1952]. Ten years later, another series of strong shocks occurred west of St. Kitts and Nevis. The strongest earthquake occurred on 2 November 1961 and was felt with an intensity of VI-VII in Nevis, V-VI in St. Kitts [Robson et al., 1962], and II in Guadeloupe [Feuillard, 1985]. The hypocentral location $\left(17.21^{\circ} \mathrm{N} ; 62.68^{\circ} \mathrm{W}, 10 \mathrm{~km}\right.$ depth, black star in Figure $2 \mathrm{~g}$ ) was given by Robson [1964]. Different magnitudes were proposed for the 2 November 1961 event (4.2 [Sykes and Ewing, 1965], 6.3 [Robson et al., 1962]). The hypocentral position of the 29 December 1950 earthquake $\left(17.0^{\circ} \mathrm{N}\right.$; $62.5^{\circ} \mathrm{W}$, depth $100 \mathrm{~km}$ ) was given by the United States Geological Survey (USGS) [Robson, 1964] but is not consistent with the intensities reported by Willmore [1952] in Nevis. Willmore [1952] and Robson et al. [1962] inferred a position at shallow depth west or southwest of Nevis.

[13] Recent high-resolution marine data of the GWADASEIS March 2009 cruise (R/V le Suroît, IFREMER [Beck et al., 2009; Leclerc, 2009; Feuillet et al., 2010]) showed that in the area of the epicenters, the southwestern border of the Nevis-St. Kitts insular shelf is crosscut by several NW-SE active faults (Nevis-St. Kitts fault system, SK-NFS) that belong to the large arc parallel right-stepping en echelon fault system (Figures 1 and 2g). The December 1950 and November 
Table 2. Updated Magnitudes, Epicenter Locations, and Depth of Historical Earthquakes Related to En Echelon Inner Arc Fault System or Subduction Zone Around Guadeloupe ${ }^{\mathrm{a}}$

\begin{tabular}{ccccccl}
\hline Date & Maximum MSK & Magnitude & Latitude $\left({ }^{\circ} \mathrm{N}\right)$ & Longitude $\left({ }^{\circ} \mathrm{W}\right)$ & Depth $(\mathrm{km})$ & \multicolumn{1}{c}{ Associated Fault System } \\
\hline $1690-04-16$ & IX & 7.0 & $17.02^{\mathrm{b}}$ & $62.28^{\mathrm{b}}$ & $15^{\mathrm{b}}$ & Montserrat-Havers/Redonda fault segment \\
$1839-01-11$ & IX & 8.0 & $14.80^{\mathrm{c}}$ & $60.30^{\mathrm{c}}$ & $30^{\mathrm{c}}$ & Eastern Martinique megathrust \\
$1843-02-08$ & IX & 8.5 & $16.73^{\mathrm{c}}$ & $61.17^{\mathrm{c}}$ & $40^{\mathrm{c}}$ & North-Eastern Guadeloupe megathrust \\
$1851-05-16$ & VII & 6.0 & $16.00^{\mathrm{d}}$ & $61.52^{\mathrm{d}}$ & $15^{\mathrm{b}}$ & Morne Piton Fault \\
$1897-04-29$ & VIII & 6.5 & $16.42^{\mathrm{c}}$ & $61.93^{\mathrm{c}}$ & $15^{\mathrm{b}}$ & Bouillante-Montserrat fault segment \\
$1897-04-29$ & VIII & 5.5 & $16.18^{\mathrm{d}}$ & $61.55^{\mathrm{d}}$ & $15^{\mathrm{b}}$ & Gosier fault \\
$1935-11-10$ & VIII & 6.2 & $16.79^{\mathrm{b}}$ & $62.33^{\mathrm{b}}$ & $15^{\mathrm{b}}$ & Montserrat-Havers fault segment \\
$1950-12-29$ & VIII & 6.0 & $17.00^{\mathrm{d}}$ & $62.50^{\mathrm{d}}$ & $15^{\mathrm{b}}$ & Nevis-St. Kitts fault segment \\
$1961-11-02$ & VII & 5.5 & $17.21^{\mathrm{f}}$ & $62.68^{\mathrm{f}}$ & $10^{\mathrm{b}}$ & Nevis-St. Kitts fault segment \\
$1974-10-08$ & VIII & 7.4 & $17.37^{\mathrm{g}}$ & $61.92^{\mathrm{g}}$ & $30^{\mathrm{g}}$ & Outer arc normal fault system \\
$1985-03-16$ & VI & 6.3 & $17.02^{\mathrm{h}}$ & $62.28^{\mathrm{h}}$ & $8^{\mathrm{h}}$ & Redonda-Nevis fault segment \\
$2004-11-21$ & VIII & 6.3 & $15.75^{\mathrm{i}}$ & $61.54^{\mathrm{i}}$ & $10^{\mathrm{i}}$ & Roseau Fault \\
\hline
\end{tabular}

${ }^{\mathrm{a}}$ For 1690 and 1935 earthquakes, epicenters have been modified from previous works, by placing them on the known active faults (see references in text). Magnitudes have been adjusted by \pm 0.5 to match reported intensities through a regional attenuation law [Beauducel et al., 2004, 2011].

${ }^{\mathrm{b}}$ This study.

${ }^{\mathrm{c}}$ From Feuillard [1985].

${ }^{\mathrm{d}}$ From Bernard and Lambert [1988].

${ }^{\mathrm{e}}$ From Robson [1964].

${ }^{\mathrm{f}}$ From Robson et al. [1962].

${ }^{\mathrm{g}}$ From McCann et al. [1982].

${ }^{\mathrm{h}}$ From Girardin et al. [1991].

${ }^{\mathrm{i}}$ From Bazin et al. [2010].

1961 earthquake sequence probably occurred along these faults.

\subsection{Earthquake of 8 October 1974}

[14] The 8 October $1974\left(M_{s}\right.$ ranging between 7.1 and 7.6) struck the northern part of the arc with intensities VIII in Antigua and Barbuda, VI in Guadeloupe, and III in Martinique [Feuillard, 1985; Tomblin and Aspinall, 1975] (Figure 2h). The aftershock distribution and the focal mechanism are compatible with a rupture in the overriding Caribbean plate on a $\mathrm{N} 70^{\circ} \mathrm{E}$ striking, southeastern dipping normal fault plane [McCann et al., 1982]. This earthquake occurred at $30 \mathrm{~km}$ depth beneath the shallow BarbudaAntigua insular shelve where no high-resolution marine data was acquired. Thus active faults were not identified in this area but the 1974 ruptured plane probably belongs to the arc-perpendicular ENE striking normal fault system well identified and mapped northeast of Guadeloupe [Feuillet et al., 2002] (Figure 1).

\subsection{Earthquake of 16 March 1985 and 21 November 2004}

[15] Together with the 150-km-deep, $M_{w}=7.4$, 29 November 2007 intermediate earthquake in the north of Martinique [Bazin et al., 2008], the 16 March $1985\left(M_{w}=\right.$ 6.3) and 21 November $2004\left(M_{w}=6.3\right)$ earthquakes, fully described in the work of Feuillet et al. [2011], are the largest events recorded in the arc in the last 25 years (Figures $2 \mathrm{i}$ and $2 \mathrm{j}$ ). They are intraplate earthquakes that ruptured faults of the inner system parallel to the arc. The 1985 earthquake was felt with an intensity of VI in Nevis and Montserrat, V in St. Kitts, IV-V in Guadeloupe, IV in St. Barthelemy, III in St. Martin, and II in Martinique [Feuillard, 1985] (Figure 2i). The damage was greater in Pointe-à-Pitre (intensity VI), probably because of a local site effect in swampy areas. The focal mechanism and the aftershock distribution are compatible with a rupture of a NW-SE striking strike-slip fault plane near Redonda [Girardin et al., 1991]. The 2004 earthquakes ruptured a $\mathrm{N} 140^{\circ} \mathrm{E}$ striking fault plane between Les Saintes and Dominica [Feuillet et al., 2011; Bazin et al., 2010] and was felt with a maximum intensity of VIII in Les Saintes (Figure 2j). The intensities determined by the inquiries of Cara et al. [2005] for the 21 November 2004 event range between IV and VIII in Guadeloupe and IV in Martinique (Figure 2j).

\section{Earthquake Magnitude Through Regional Attenuation Law for Seismic Intensities}

[16] A regional attenuation law for seismic intensities (see Appendix A) gave us the opportunity to verify or reassess the magnitude of the Lesser Antilles significant historical earthquakes from observed intensities. We reported in Table 2 the location of earthquake epicenters used in our calculations. When unknown, we inferred a depth of $15 \mathrm{~km}$ for intraplate earthquakes. We verified that the results do not change significantly by using shallower depths. Modeled isoseismal maps for each earthquake are presented in Figure 3.

[17] By considering that the April 1690 earthquake occurred between Antigua, St. Kitts, and Nevis, where the largest intensities were reported, along the MontserratHavers and Redonda fault system, we calculated that a $M \approx 7$ shallow hypocenter as proposed by Feuillard [1985] is in good agreement with all reported intensities within uncertainties. In this case, following the Wells and Coppersmith [1994] relationship between rupture length and magnitude, the 1690 earthquake would have broken a 50-km-long fault segment (dashed area in Figure 2a).

[18] For the largest earthquakes of 1839 and 1843, our models tend to show that the magnitudes were underestimate. All intensities available in the literature are reported in Figure 4. We showed that a magnitude of 8 instead of $M \approx$ 7.5 as proposed by Feuillard [1985] is in better agreement with the reported intensities for the 11 January 1839 

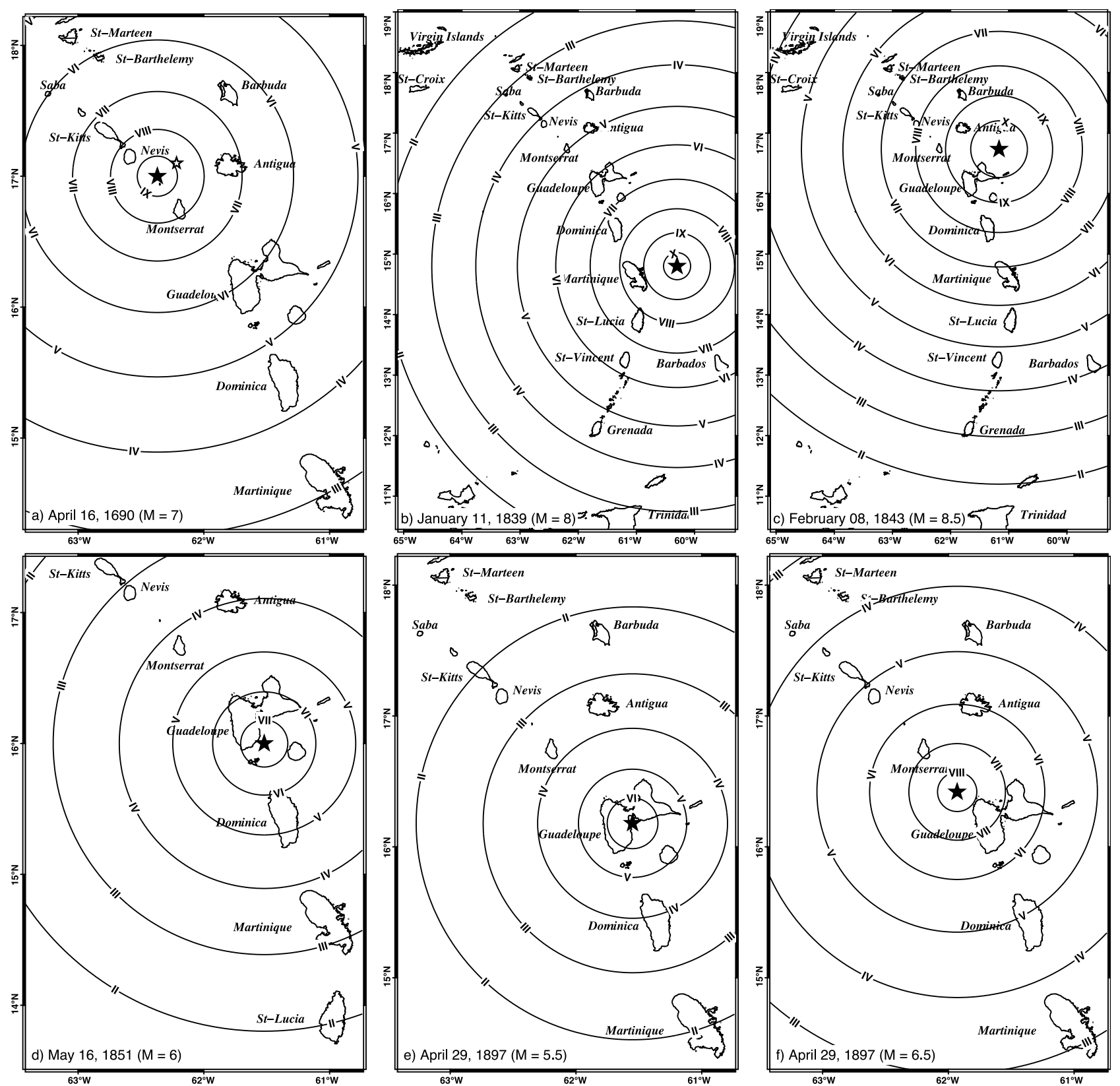

Figure 3. (a-1) Simulated intensities for earthquakes presented in Figure 2, calculated by using a regional attenuation law for macroseismic intensities, within \pm 1 degree of uncertainty [Beauducel et al., 2004, 2011] (see Appendix A and Figure A1). Some magnitudes have been adjusted within \pm 0.5 to fit better the reported intensities for each event. White and black stars as in Figure 2. Figures $3 \mathrm{e}$ and $3 \mathrm{f}$ show the two different hypothesis for the 29 April 1897 earthquake. See details and discussion in section 3 and Appendix A.

earthquake (Figures $3 \mathrm{~b}$ and $4 \mathrm{a}$ ). For the February 1843 earthquake, the B3 law predicts that a magnitude more than 8 with a mean value of 8.5 account well for most of the reported intensities including those reevaluated by Bernard and Lambert [1988] (Figures 3c and 4b) in agreement with the magnitude estimated by Robson [1964] and Shepherd [1992]. One might notice that maximum intensities reported for the numerous $M>8.5$ megathrust earthquakes since 2004 in Sumatra, Chile, and Japan have reached VIII and locally IX (USGS data on http://earthquake.usgs.gov), whereas smaller
$M<8$ earthquakes were rather felt with maximum intensities of VII-VIII (in the closest areas, above the rupture). It seems unlikely that the 1843 earthquake was smaller than magnitude 8 since intensities of IX and perhaps X [Shepherd, 1992] were reported on several islands.

[19] By considering a rupture along the Morne-Piton fault system, the B3 simulation predicts a magnitude 6 earthquake for the 16 May 1851 earthquake within the uncertainty of 1 degree of MSK scale (Figure 3d) implying a 10-km-long rupture along the Morne-Piton fault system (Figure $2 \mathrm{~d}$ ). 

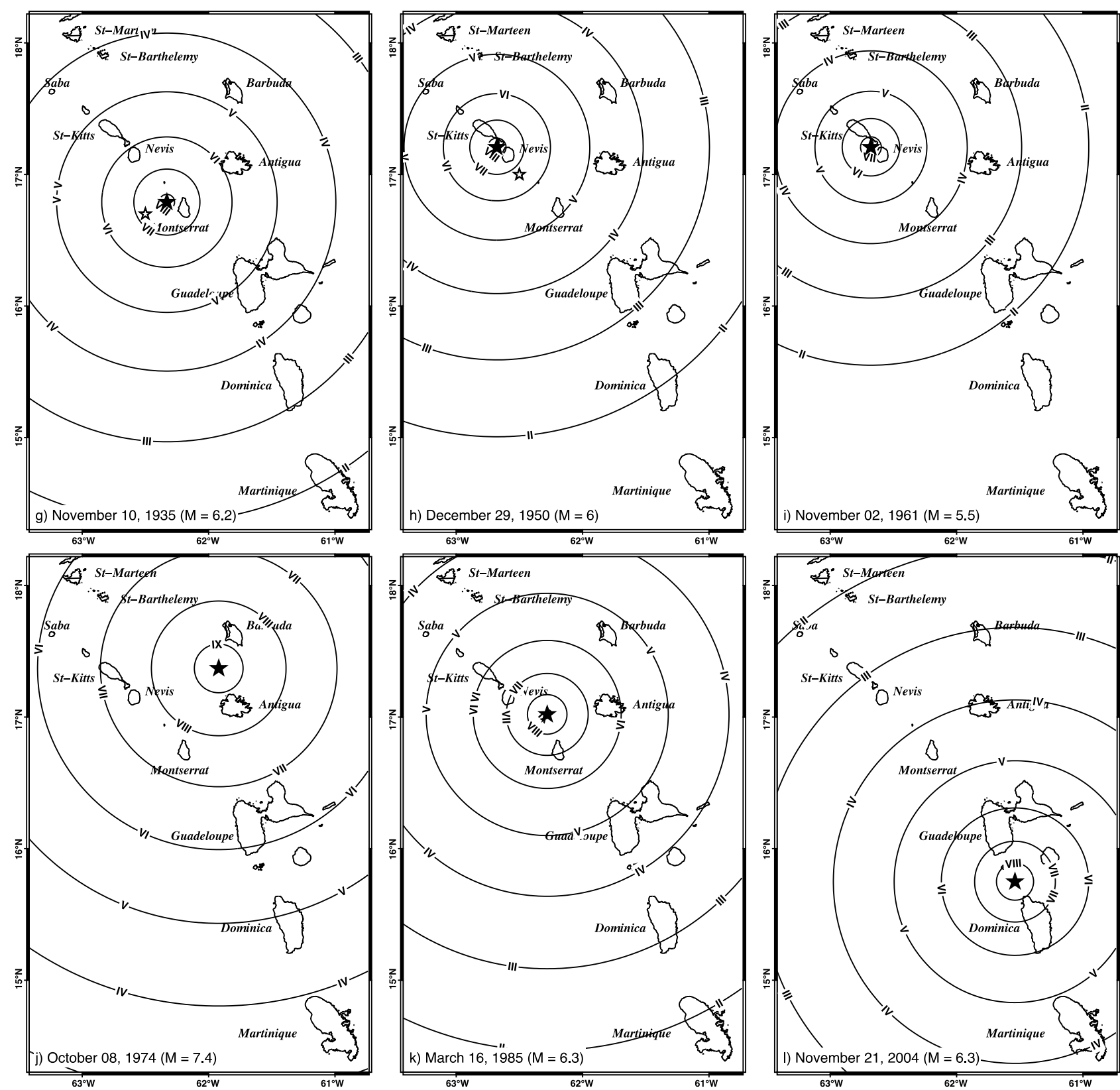

Figure 3. (continued)

[20] An epicenter northwest of Deshaies as proposed by Feuillard [1985] along the Bouillante-Montserrat faults for the 29 April 1897 earthquake, albeit with a smaller magnitude than he estimated (6.5), would fit all reported macroseismic intensities for this event (Figure 3f). Using Bernard and Lambert's [1988] hypothesis, a magnitude of 6, rather than 5.5 , would be more suitable with intensities observed in Guadeloupe but would imply a maximum intensity of II-III in Nevis (see Figure 3e), inconsistent with that reported (V). Such magnitudes would be compatible with ruptures longer than $10 \mathrm{~km}$ on Bouillante-Montserrat or Gosier faults (dashed areas in Figure 2e).
[21] For the magnitude 6.2, 10 November 1935 earthquake, B3 simulation is incompatible with a hypocentral depth of $100 \mathrm{~km}$ as proposed by Gutenberg and Richter [1954], producing maximum intensity of only IV-V in Montserrat, and III-IV in Antigua. By considering that the earthquake was superficial and occurred along the Montserrat-Havers fault system, we have shifted the epicenter by hand by a few kilometers, toward the northeast, along the fault zone. By using these new position and a crustal depth of $15 \mathrm{~km}$, the B3 simulations fit much better, with intensities reported in Montserrat (VII-VIII), Antigua (V-VI), and St. Kitts (see Figure $3 \mathrm{~g}$ ). 

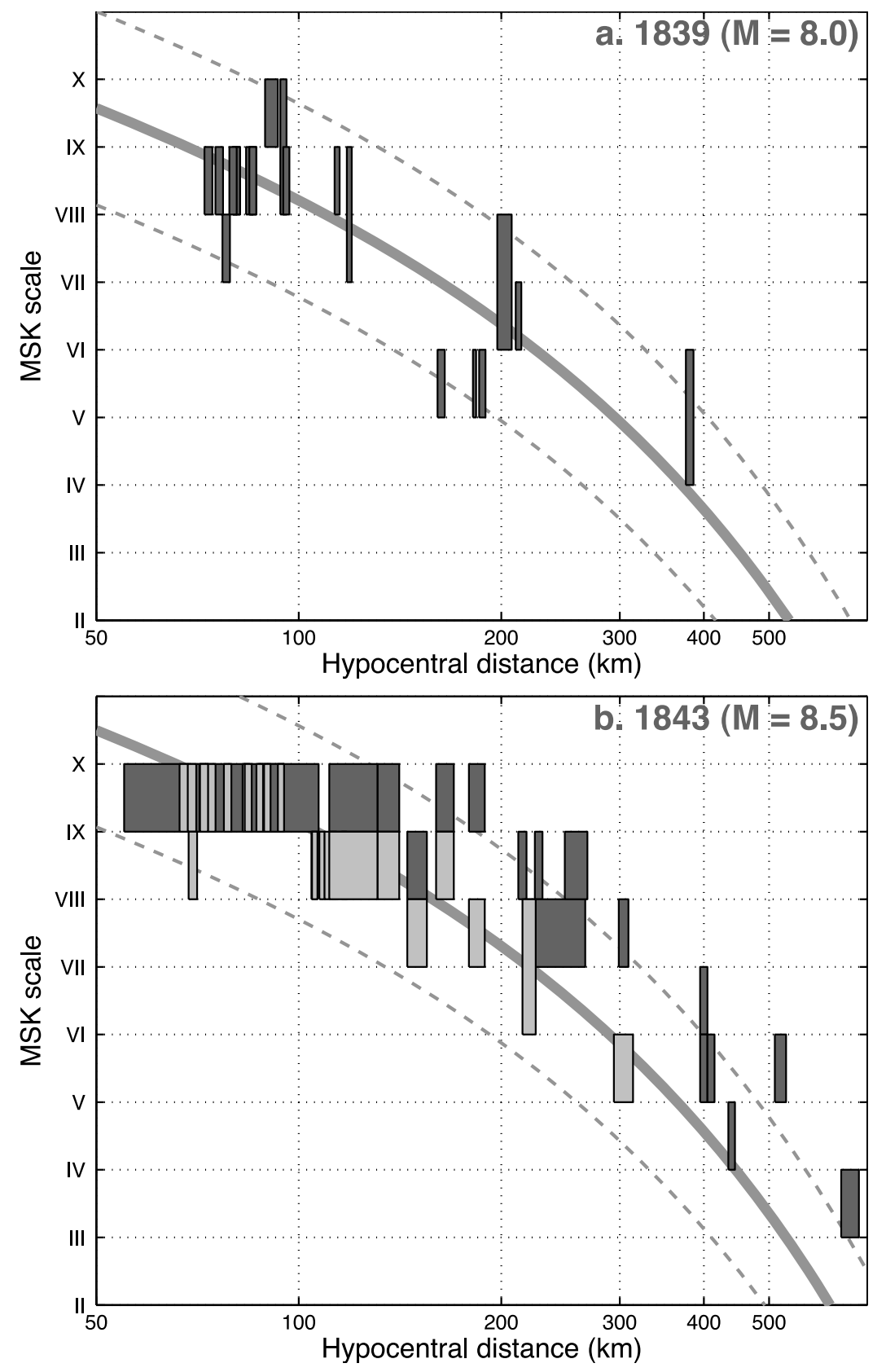

Figure 4. Reported and modeled intensities versus hypocentral distance for 1839 and 1843 earthquakes. Thick gray lines indicate simulated intensities for a given magnitude and gray dashed lines indicate associated uncertainty. (a) The 11 January 1839, simulated intensities for a magnitude 8.0, where dark gray rectangles indicate reported intensities after Feuillard [1985] (http://www.sisfrance.fr), and (b) the 8 February 1843 simulated intensities for a magnitude of 8.5 , where dark gray rectangles indicate reported intensities after Robson [1964] and Shepherd [1992] and light gray rectangles indicate reported intensities after Bernard and Lambert [1988] (see Appendix A for details).

[22] Shallow epicenters along the en echelon system, close to Nevis, and magnitude 6 and 5.5 for the 1950 and 1961 earthquakes respectively agree well with the reported intensities in Nevis, St. Kitts, Guadeloupe, and Antigua (Figures $3 \mathrm{~h}$ and 3i). We verified that a depth of $100 \mathrm{~km}$ for the 29 December 1950 as proposed by Robson [1964] is not compatible with the reported intensities. Simulated intensities for the 16 March 1985 earthquake agree well with observa- tions (Figure 3k), except in Pointe-à-Pitre (IV-V instead of $\mathrm{VI})$.

\section{Time Correlations Between Earthquakes and Volcanic Unrest}

[23] There is a clear spatial correlation between the intraplate faults and volcanoes in the Lesser Antilles arc 
[Feuillet, 2000; Feuillet et al., 2001, 2010] (Figure 1). Several volcanic complexes and hot spring sets, between Nevis and Martinique, are elongated in a N130 $\pm 20^{\circ} \mathrm{E}$ direction, roughly parallel to fault segments of the large trench-parallel en echelon system [Feuillet et al., 2002, 2004a]. Some edifices (Soufrière of Guadeloupe and Montserrat) lie at the intersection between the latter faults and the western tips of the arc-perpendicular graben. Given the collocation of active and recent volcanic vents and faults, it appears that faulting and volcanism are organically connected and likely interact.

[24] Time correlations between earthquakes and volcanic eruptions have been observed worldwide. In Chile, The Cordon Caulle volcano erupted two days after the 22 May $1960 \mathrm{M}=9.5$ Chile earthquake [Barrientos, 1994]. Watt et al. [2009] have shown that $M>8.0$ earthquakes, particularly those of 1906 and 1960 were followed by a significant increase in eruption rate along the Chilean subduction zone. In Sumatra, the Talang volcano erupted a few days after the 28 March $2005 \mathrm{M}=8.7$ earthquake [Walter and Amelung, 2007]. Mount Pinatubo erupted in 1991, a few months after the $M_{s}=7.8$ Luzon earthquake [Bautista et al., 1996].

[25] Interaction between the two phenomena are however not well understood. Several triggering mechanisms are proposed in the literature [e.g., Brodsky et al., 1998; Nostro et al., 1998; Linde and Sacks, 1998; Hill et al., 2002; Marzocchi, 2002; Walter and Amelung, 2007, and references therein]. All appealed static or dynamic stress changes. Coseismic slip-induced static stress changes are permanent over several years and decay rapidly with distance to fault. They may precipitate unrest or eruptions within few days, months, and perhaps years at neighboring volcanoes [Nostro et al., 1998; Watt et al., 2009]. Postseimic viscoelastic relaxation may induce stress perturbations over several decades and account for longer time scale interactions [Marzocchi, 2002], whereas transient coseismic dynamic stress changes due to seismic waves propagation may trigger eruptions in the far field [Linde and Sacks,1998; Brodsky et al., 1998; Manga and Brodsky, 2006].

[26] To investigate time correlations between earthquakes and volcanic unrest in the Lesser Antilles, we selected in the historical catalogs all $M \geq 6$ earthquakes felt with intensities ranging from VI to IX, strong enough to have induced significant stress perturbation beneath volcanoes. This corresponds to 26 events. We considered as a volcanic event any isolated (not followed by an eruption within one year) significant seismic swarm (with felt events only), phreatic or magmatic eruptions. This corresponds to 44 volcanic events (about 0.12 eruption/year). Figure 5 shows the cumulative number of earthquakes and volcanic events. Inferring that the long-term seismicity and eruption rates were constant over historical period, our record is approximately complete after 1800 . Figure 5 shows a striking correlation between the two phenomena at the scale of the arc. Both curves reveal two concomitant increases in seismicity and eruption rates from the mid-19th century until the beginning of the 20th century.

[27] All eruptions and earthquakes are reported in Figure 6. We first looked at time correlations between neighboring earthquakes and volcanoes and then we made statistical analysis at the scale of the arc to discuss the link between volcanoes and larger interplates earthquakes.

\subsection{Soufrière of Guadeloupe}

[28] In Guadeloupe, the last large magmatic eruption, which led to the emplacement of the Soufrière dome, occurred in $1530 \mathrm{AD}$ [Boudon et al., 2008], before the first European settlement. A small phreatic eruption reported in 1690 might be interpreted to have followed the April 1690 earthquake [Komorowski et al., 2005]. But there was no report of volcanic or geothermal activity at La Soufrière [Sainte-Claire Deville, 1843] after the 8 February 1843 earthquake.

[29] By contrast, the large, July 1976 to March 1977 phreatic eruption of the Soufrière occurred less than 2 years after the magnitude 7.4, 8 October 1974, a few tens of kilometer farther north. That event had an immediate effect on the volcano. The earthquake occurred at 0950 UTC and a seismovolcanic swarm started under it about $25 \mathrm{~min}$ later [Feuillard, 1985; IPGP, 2008]. Several tens of earthquakes were recorded by the seismic network (Figure 7). The seismic activity returned in few hours to a normal level but increased again in November 1975 with more than 200 events recorded during the month, most of them having occurred on 25, 26, and 27 November. Only few tens to hundred earthquakes per month occurred between December 1975 and beginning of March 1976, but 5 days after a moderate event $\left(M_{w}=5.7\right)$ on 10 March 1976, east of Grande-Terre (Figure 1), the number of earthquakes increased again, with more than 600 shocks recorded in the following weeks, 22 felt by the population. Between April and June, few days before the beginning of the Soufrière phreatic eruption on 8 July 1976, more that 600 earthquakes were recorded per month [Beauducel and Besson, 2008]. The 8 October 1974 earthquake may have trigger the 1976 Soufrière phreatic eruption.

[30] Intensified monitoring of the Soufrière volcano was performed by the observatory staff for many weeks after the 21 November 2004 earthquake. The chemical composition of geothermal sources around the volcano, in particular, was measured almost daily. To this day however, no anomalous seismic or geochemical signal was detected. The seismic and fumarolic activity near and on the Soufrière dome appears to have remained constant with the exception of the large landslides triggered by coseismic shaking on its southern flank.

\subsection{Soufrière Hills of Montserrat}

[31] Radiocarbon dating of charcoal samples [Young et al., 1996] indicates that the Soufrière Hills erupted in AD $1624 \pm$ 72 years. Statistical analysis of ages distribution suggests two distinct eruptions in AD $1540 \pm 35$ and in AD $1667 \pm 40$ [Shepherd et al., 2002]. Following these authors, the second eruption occurred after the European settlement within 95\% of confidence but was surprisingly not mentioned in local chronicles of the time. Given the uncertainty in ${ }^{14} \mathrm{C}$ dates, this latter eruption might have occurred close to the April 1690 earthquake. The lower boundary of the radiocarbon ages does not exclude that it occurred before the settlement of Europeans, however. 


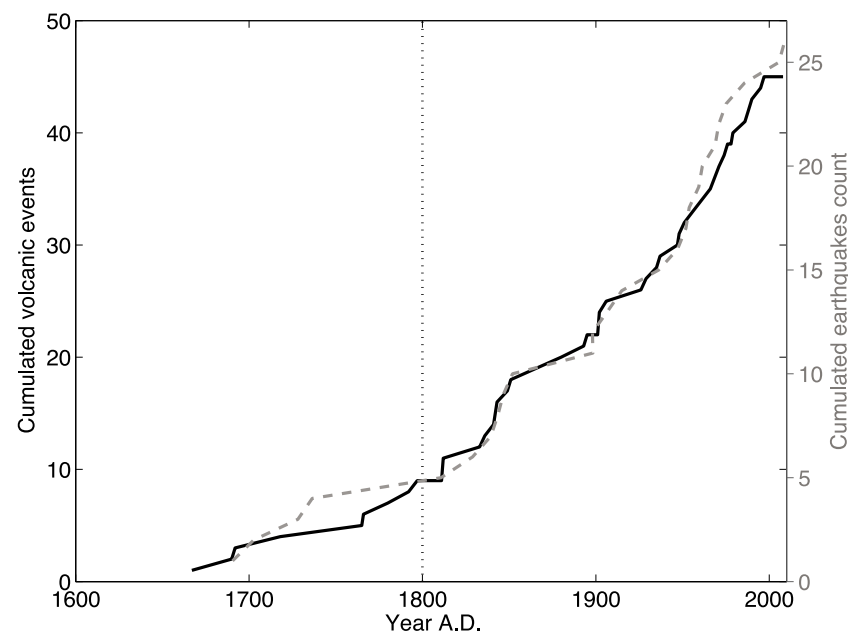

Figure 5. Cumulative number of volcanic unrest or eruptions (solid black line) and earthquakes felt with intensities from VI to IX in the Lesser Antilles (gray dashed line). Volcanic events are any isolated significant seismic swarms (with felt events) or phreatic or magmatic eruptions. Assuming a constant long-term rate of volcanic and seismic activity, the record can be assumed to be complete after $\sim 1800$ (vertical dotted line). A remarkable correlation between volcanic and seismic activity is observed from the middle of 19th to the beginning of 20 th century.

[32] The large 8 February 1843 earthquake apparently had an effect on the geothermal activity of Soufrière Hills. Following this earthquake, a zone of fumaroles reportedly formed during the year 1843 in the Upper Gage area [Hincks et al., 2005].Also, according to the same author, a period of severe seismic activity, with several damaging shocks, some reaching intensity VIII [Robson, 1964] and possibly concurrent geothermal activity, occurred in Montserrat between 23 and 27 April 1897, a few days before the 29 April 1897 earthquake. Such seismic activity might in fact have begun as early as 1895 and continued until 1900 or 1902 [Shepherd et al., 2002]. Another volcano-tectonic crisis occurred at Montserrat between 1933 and 1937 with more than 3290 earthquakes felt and activity at the hot springs [Shepherd et al., 2002]. The seismicity reached a peak in October 1935, one month before the 10 November 1935 regional earthquake. After Perret [1939] quoted by Shepherd et al. [2002], the latter shock triggered a rapid sequence of strong volcanic earthquakes, whose number then decreased quickly to reach few tens of felt events per month until the end of the volcano-tectonic crisis in 1937 [Shepherd et al., 2002].

[33] The 16 March 1985 earthquake and its main aftershock of February 1986 had triggered seismic activity in Montserrat. Several bursts of earthquakes were recorded only in Montserrat during the seismic sequence [Shepherd et al., 2002]. The seismic network was unfortunately destroyed in 1989 by Hurricane Hugo and restored only in 1992. Since this period, it recorded a growing rate of seismicity until the beginning of Soufrière Hills eruption in 1995, after 300-year-long period of dormancy since the previous 17 th century eruptions. The still ongoing eruption involved several phases of growth and collapse of the dome. That the
16 March 1985 earthquake and volcanic activity at Soufrière Hills occurred only few years apart, after long intervals of either seismic or volcanic quiescence, is suggestive of a causal relationship.

[34] More recently, in November 2008, several quite strong superficial earthquakes occurred between Nevis and Montserrat [Institut de Physique du Globe de Paris (IPGP), 2008]. The main shock reached a magnitude 4.8 and struck Nevis on 2 November. It was followed by several aftershocks that occurred in a zone trending NW-SE, in the westward continuation of the 1985 rupture, suggesting that they ruptured the same en echelon fault system. This crisis has coincided with a strong resurgence of activity in Montserrat in late 2008 and the collapse of the Soufrière Hills dome, 4 months later, in February 2009 (Montserrat Volcano Observatory reports, on http://www.mvo.ms).

\subsection{St. Kitts and Nevis}

[35] Historical reports mention two volcanic eruptions in St. Kitts, north of Nevis, in 1692 and 1843, following the 1690 and 1843 earthquakes, respectively [Robertson, 2005a]. Capadose [1845], quoted by Robertson [2005a], described clouds of smoke and a bubbling sulphurous spring from the active crater of Mt. Liamuiga in 1843. Confusions between the earthquakes and eruptions could be the source of such reports, however [Robertson, 2005a]. The 29 December 1950 and 2 November 1961 earthquakes west of Nevis were followed a few weeks later by seismic swarms beneath Nevis peak, the active volcano of the island [Willmore, 1952; Robson et al., 1962]. Following the 1950 shock, a new "Soufrière" (fumarolic activity) began to form at Cades Bay in the northeast part of Nevis in 1953 [Robson et al., 1962]. Finally, an earthquake swarm occurred beneath Mt. Liamuiga in St. Kitts, with two events of magnitude up to 4.3 and 4.6 [Robertson, 2005a], on 24 October 1988, about 3 years after the 16 March 1985 earthquake.

\subsection{Dominica, Mt. Pelée, St. Vincent, and St. Lucia}

[36] On 5 August 1851, 3 months after the 16 May 1851 earthquake in southern Guadeloupe, Mt. Pelée in Martinique was the site of several phreatic explosions involving blocks and ash falls. The catastrophic eruption of Mt. Pelée in 1902, and a coeval one at the Soufrière of St. Vincent occurred 5 years after the 29 April 1897 earthquake. Earthquake swarms were reported in 1841 and 1849 beneath the Desolation valley in Dominica [Lindsay et al., 2005] after the 1839 and 1843 earthquakes.

[37] A volcanic seismic swarm with a great number of reported felt events occurred in St. Lucia after the magnitude 7, 16 February 1906 earthquake offshore this island [Lindsay, 2005]. The Boiling Lake in Dominica is reported to have drained out completely following the 21 November 2004 shock in relation to earthquake induced dilation at the rupture tips [Feuillet et al., 2011].

\subsection{Statistical Study at Regional Scale}

[38] As evidenced by an increase in slope as shown in Figure 5, numerous seismic and volcanic events took place in the central part of the arc, between the middle of the 19th century and the beginning of the 20th century (Figure 1). It started on 11 January 1839, with the largest known earthquake reported in Martinique. This event was followed 


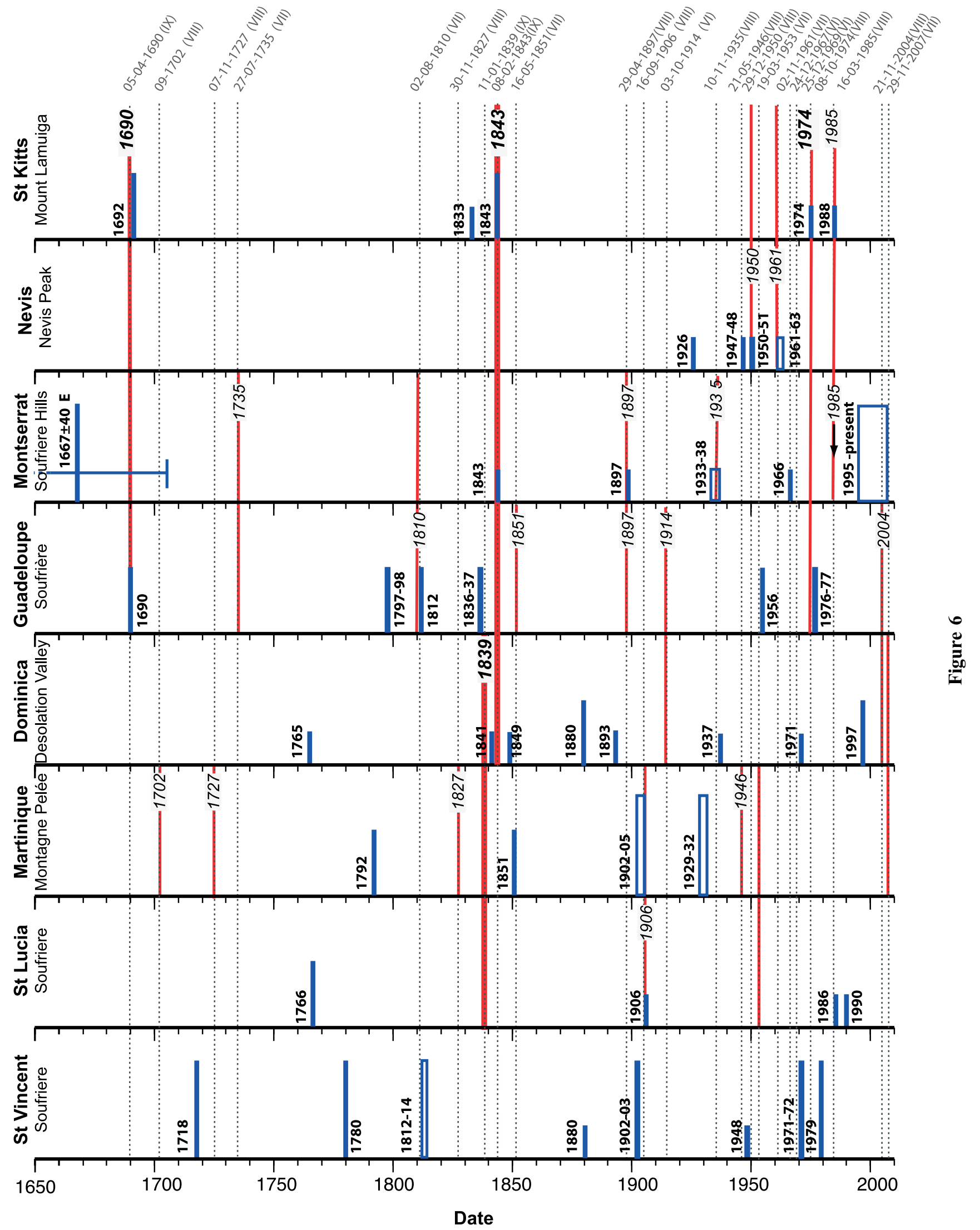




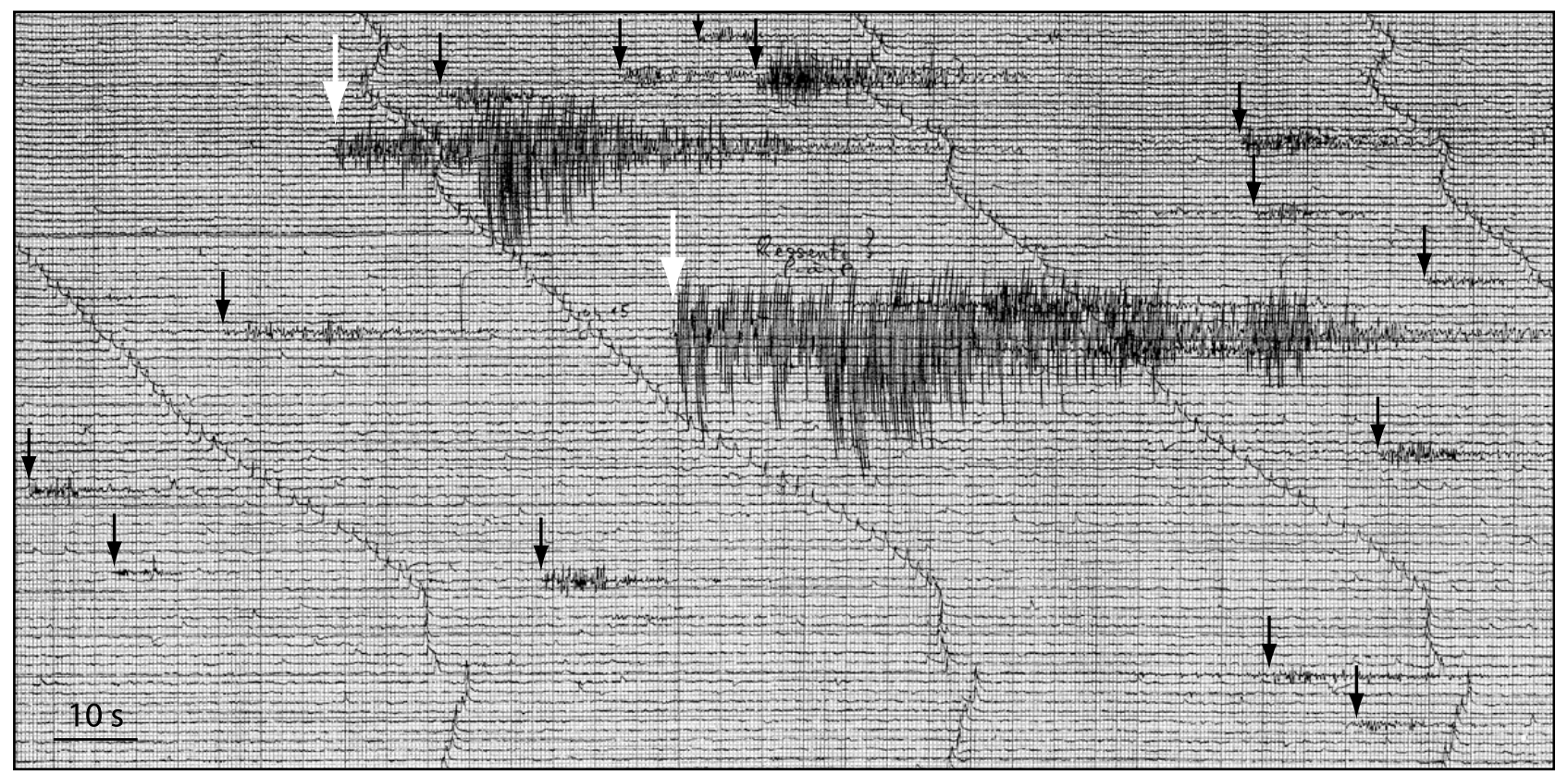

Figure 7. Original drum paper sample scanned from IPGP Guadeloupe Observatory archives showing the earthquakes recorded near the Soufrière dome in Guadeloupe (Carmichal short period station) a few hours after the 8 October 1974 earthquake. P wave arrivals of earthquakes that occurred under the volcano are indicated by black arrows. Wave arrivals of 8 October 1974 aftershocks are indicated with a white arrow. At least 14 volcanic earthquakes and two main aftershocks are recorded on this sample.

4 years later by the 8 February 1843 . The 16 May 1851 Capesterre earthquake, 8 years after, was followed only 3 months later by phreatic eruptions at Mt. Pelée. About 4 decades later, the April and May 1897 events struck Guadeloupe preceded by strong shocks in Montserrat a few days before. A few years earlier, on 4 January 1880 , one of two known historical phreatic eruptions had occurred in the Desolation Valley of Dominica. Finally, 5 years after the 1897 earthquake, both the Soufrière of St. Vincent and Mt. Pelée erupted simultaneously, the latter in the devastating eruption that annihilated St. Pierre. This sequence is particularly remarkable given the near temporal coincidence of events (days, months, or years) and long return times, on order of several hundred years. It is also remarkable that during this half century of climactic volcanic and seismic activity, in November 1867, the Virgin Islands were struck by the largest earthquakes ever reported in the northern part of the arc with highest intensities (VIII-IX) in western Virgin Islands (St. Thomas, St. Croix) and eastern Puerto Rico (VIII) [Reid and Taber, 1920] (Figure 1 inset).
[39] In Figure 8, following the statistical method described by Watt et al. [2009], we compared the evolution of eruption rate to earthquake occurrence. Our data set being too sparse to use narrower windows, we calculated the eruption rates at one year increments with 3, 5, and 10 year moving sums. Figure 8 shows an increase of eruption rate following the mid-19th century largest subduction earthquakes (1839 and 1843), with a maximum of three and four volcanic events in the following 3 and 10 years, respectively. The eruption rate has also increased in correlation with the occurrence of the 16 April 1690, 2 August 1810, 10 November 1935, 21 May 1946, and 16 March 1985 earthquakes and at the end of the sixteens after three $M>6$ earthquakes on 24 December 1967, NE of Antigua (Figure 1), 25 December 1969 (Christmas sequence in the subducting American plate [Stein et al., 1982] (Figure 1 inset)), and 8 October 1974.

[40] By using a 5 year window, five main peaks of volcanic activity (with three events in 5 years) correlate with the 1839-1843, 1897, 1946, 1967 to 1974, and 1985

Figure 6. Temporal correlation between $I \geq$ VI earthquakes and volcanic activity. Gray vertical dashed line indicates dates and maximum intensities of earthquakes, with thicker lines for larger intensities ( $I \geq \mathrm{VIII})$. Red vertical solid line indicates static stress areas of significant interaction between an earthquake and neighboring volcanoes, i.e., at distances of about three time the fault length (estimated from earthquake magnitude using Wells and Coppersmith [1994] formulation). Blue ticks with dates indicate dates and type of volcanic activity (shorter length indicates seismic swarm, medium length indicates phreatic eruption, and longer length indicates magmatic eruption), and line width indicates the time duration of volcanic event. Information on historical events from Bernard and Lambert [1988], Boudon et al. [2005], Feuillard [1985], Hincks et al. [2005], Komorowski et al. [2005], Lindsay [2005], Lindsay et al. [2005], Robertson [2005a, 2005b], Robson et al. [1962], Robson [1964], and Simpson [2005]. 

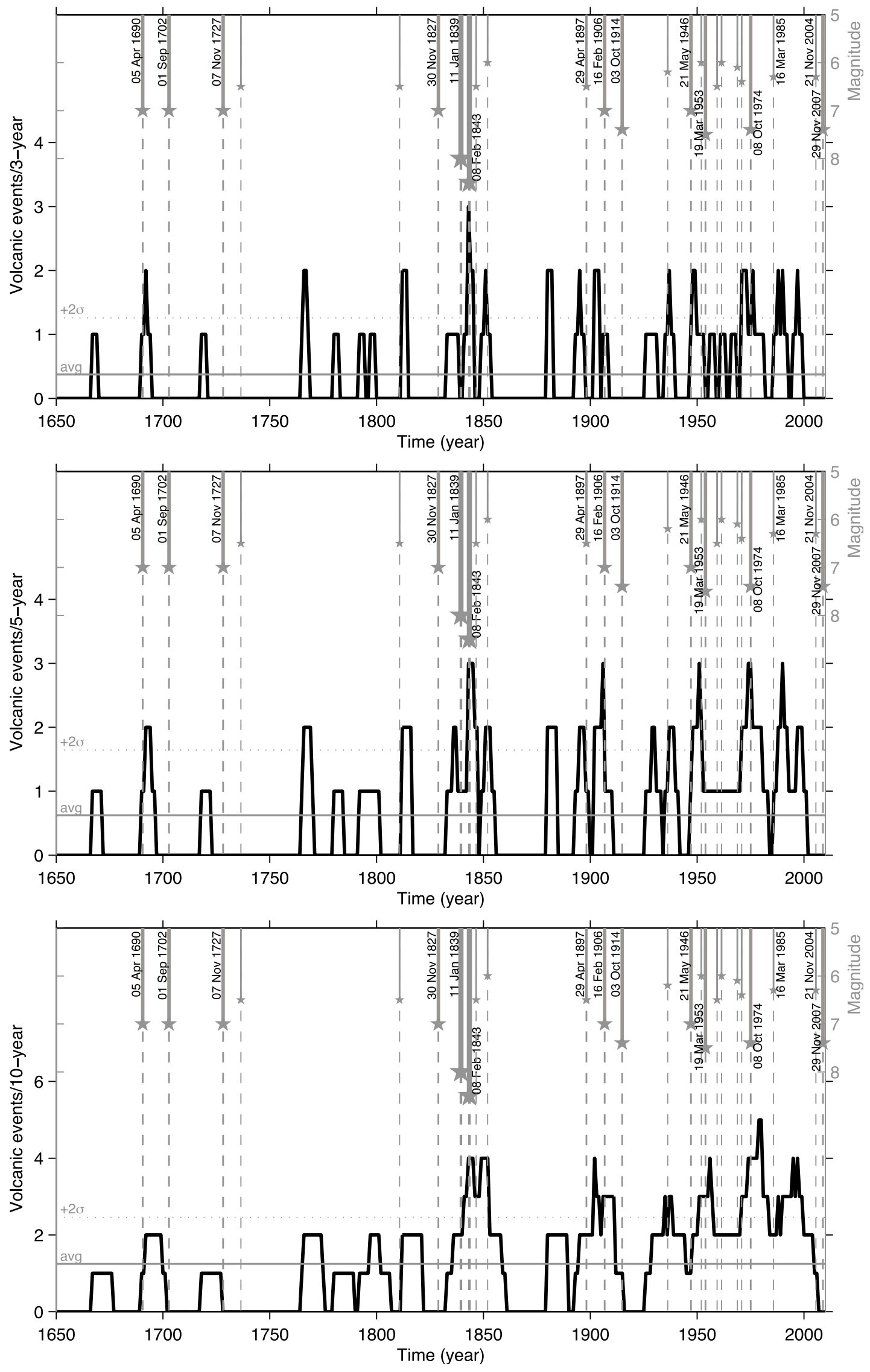

Figure 8 
earthquakes. By using a 10 year window, we showed that a main peak of volcanic activity (five events in 10 years) occurred after the 8 October 1974 earthquake. In the following, we seek to understand this correlation by calculating the stress changes imparted by historical earthquakes to the volcanoes plumbing system (magmatic chambers and dikes).

\section{Stress and Strain Modeling}

[41] Several examples of static stress interactions between earthquakes and volcanoes are described in the literature. In Italy, Nostro et al. [1998] have shown that large normal faulting earthquakes along the Apennines induced small static stress changes ( 0.01 to $0.1 \mathrm{MPa})$, sufficient to have promoted Vesuvius eruptions few years later by compressing its magmatic chamber at depth and/or by opening suitably oriented dikes at the surface. Feuillet et al. [2006] have modeled the effects of large earthquakes in Sicily on eruptive activity at Mount Etna and shown that earthquakes induce changes in eruption rates. Barrientos [1994] and Walter and Amelung [2007] have shown that extensional strain increase induced by large megathrust earthquakes beneath volcanic arcs may have brought volcanoes closer to eruption. In all cases, the static stress perturbations are small if compared to tectonic stresses, lithostatic pressures, and magmatic chamber overpressures. They are, however, two orders of magnitude higher than the stress changes induced by ocean tides for which time correlation with volcanic activity has been observed in several cases [e.g., Kasahara, 2002].

\subsection{Intra-arc Earthquakes}

[42] The 8 October 1974, 16 March 1985, and 21 November 2004 earthquakes are the largest intraplate event recorded in the last decades. They occurred close to the Montserrat and Guadeloupe volcanoes, within regions where eruption triggering by static stress change is most likely [Nostro et al., 1998; Walter and Amelung, 2007]. To test the effect of these earthquakes on the volcanoes, we calculated the horizontal normal stress changes perpendicular to dike or dike-shaped reservoirs $\left(\sigma_{n}\right)$ and the pressure change $\left(\Delta P=\sigma_{k k} / 3\right)$ around spherical magma chambers induced by a dislocation in an elastic half-space with $\lambda=32 \mathrm{GPa}$.

[43] Although there is no compelling evidence to assess reservoir depths beneath the volcanoes, Aspinall et al. [1998] and Mattioli et al. [1998] inferred a minimum depth of about 5-6 km for the magma chamber in Montserrat, on the basis of seismic event locations and GPS modeling. The seismicity beneath the Soufrière of Guadeloupe being usually located in the first $4 \mathrm{~km}$ [Bazin et al., 2005], we infer that its magma reservoir is also located at about $5 \mathrm{~km}$ depth. Both volcanoes stand at intersections between inner and outer arc fault systems and are probably fed by sets of dikes striking NW-SE to ENE-WSW [Feuillet et al., 2002]. The
Soufrière of Guadeloupe, for instance, is located at the western end of the Marie-Galante graben, with several young domes aligned along an E-W striking fissure [Feuillet et al., 2002]. Its dome is principally cut by $\mathrm{N} 155 \pm 25^{\circ} \mathrm{E}$ striking faults, compatible with NE extension. In Montserrat we inferred to main sets of dikes $\left(\mathrm{N} 115^{\circ} \mathrm{E}\right.$ along the inner arc en echelon system and $\mathrm{N} 70^{\circ} \mathrm{E}$, parallel to arc-normal faults located in the outer arc, north of Guadeloupe). We calculate the pressure as well as normal stress changes perpendicular to dikes and show the results in maps at $5 \mathrm{~km}$, for Soufrière of Guadeloupe, and $6 \mathrm{~km}$ depth for Soufrière Hills and along E-W cross-sections beneath the volcanoes (Figure 9).

[44] At Soufrière Hills of Montserrat, the 1985 earthquake increased the static pressure and decrease the normal stress (considered here as positive for extension) along $\mathrm{N} 115^{\circ} \mathrm{E}$ and $\mathrm{N} 70^{\circ} \mathrm{E}$ striking dikes, by more than 0.02 and $0.04 \mathrm{MPa}$, respectively. The stress induced by the 21 November 2004 shock and its main aftershock on Guadeloupe's Soufrière volcano is smaller and of opposite sign. The 2004 earthquake contributed to decrease the pressure and increase the normal stress by about $0.01 \mathrm{MPa}$ around a $5-\mathrm{km}$-deep spherical reservoir or on $\mathrm{N} 140^{\circ} \mathrm{E}$ and $\mathrm{E}-\mathrm{W}$ trending dikes and dike-shaped magma bodies. The 8 October 1974 induced compressive stress on both volcanoes with higher values $(>0.05 \mathrm{MPa})$ in Montserrat. No volcano-tectonic activity was however reported at Soufrière Hills after this event. At Soufrière of Guadeloupe, the compressive stress changes range between 0.01 and $0.04 \mathrm{MPa}$ and are larger on E-W striking dikes.

\subsection{Interplate Earthquakes}

[45] The clustering of large earthquakes and volcanic unrest at the end of the 19th century along the northern arc suggests stress coupling between these events. Considering that the 1839 and 1843 earthquakes ruptured the subduction interface, we calculated the coseismic Coulomb stress, as well as the normal and volumetric strain changes, imparted by these events to the inner arc intraplate shallow faults and volcanoes, respectively.

[46] We model the 1843 earthquake by $15 \mathrm{~m}$ of dislocation on a $300-\mathrm{km}$-long, shallow-dipping $\left(20^{\circ}\right)$ plane, extending between Antigua and Dominica (Figure 1). We consider that this earthquake ruptured the whole plate interface between its 15-km-deep updip limit [Bangs et al., 2003; Roux, 2007] and $30 \mathrm{~km}$ depth. We take the same dip for the 1839 earthquake but infer a smaller rupture size (a length of $140 \mathrm{~km}$ and a slip of $8 \mathrm{~m}$ ). Such dislocation models are consistent with magnitudes of 8.5 and 8.0 for the 1843 and 1839 events, respectively.

[47] The results show that the 1839 and 1843 earthquakes increased the Coulomb stress along the whole inner arc fault system (Figure 10c), with the highest values $(>0.5 \mathrm{MPa})$

Figure 8. Volcanic activity rate from 1650 to 2009 in correlation with earthquakes occurrence represented with gray bars with stars. Earthquake catalog as in Figure 5 with longer bars for larger magnitudes. Rates are computed using (top) 3-year, (middle) 5-year, or (bottom) 10-year moving sum over the volcanic record at 1-year increments, such that only volcanic events prior to the time point contribute to the volcanic activity rate (causal method). Using these calculated rates the mean and +2 standard deviation lines are shown to assess rate variability and show the degree of deviation from the background. 

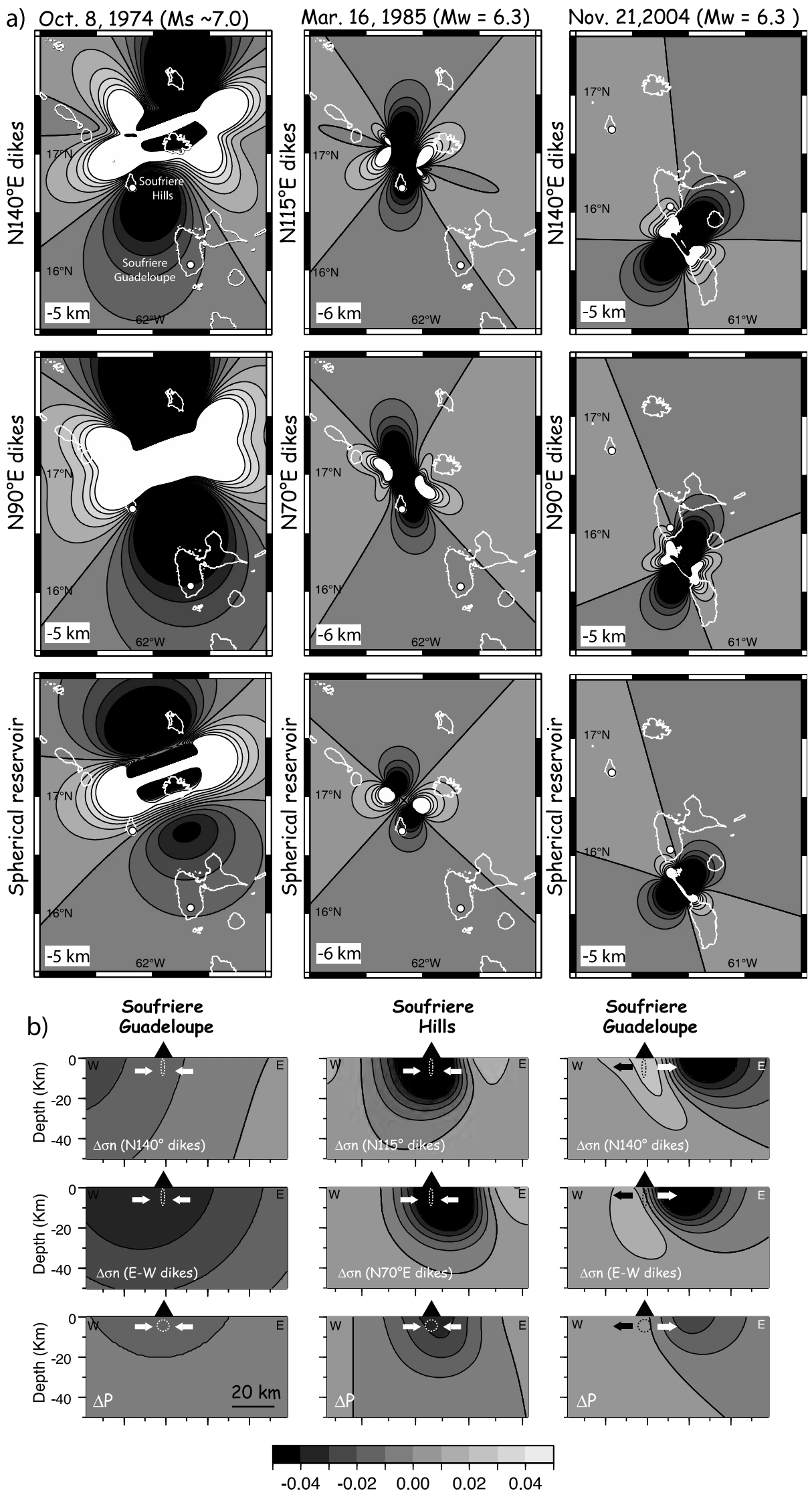

Dike closing / Pressure Changes (MPa)

Figure 9

17 of 26 


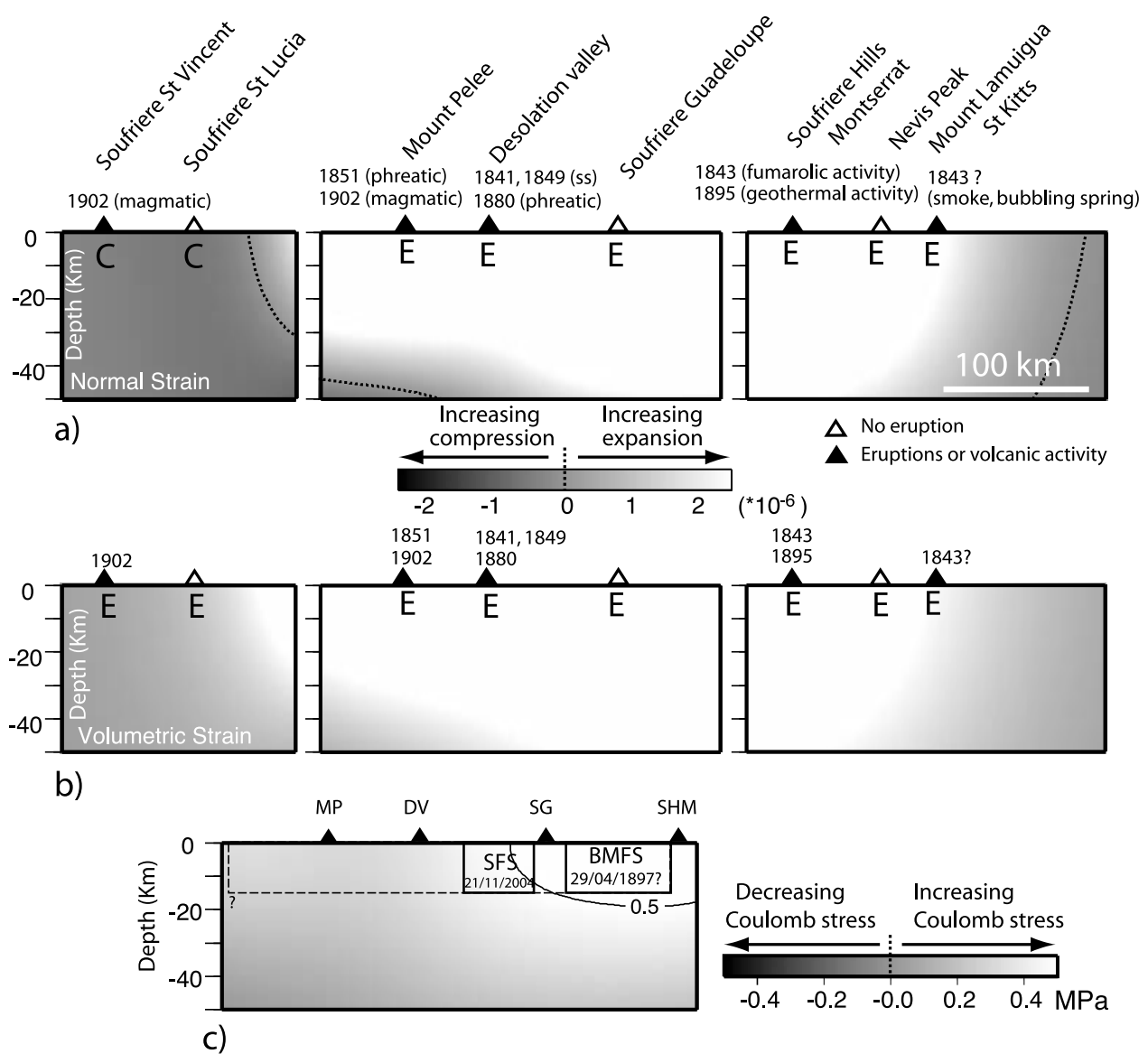

Figure 10. ( $a$ and b) Normal and volumetric strain induced beneath the volcanic arc by the 1839 and 1843 earthquakes, respectively. The strain changes are calculated in a homogeneous elastic halfspace and are shown along a three vertical cross sections, parallel to the subduction zone, the modeling accounting for the curvature of the trench. The normal strain is calculated along dikes or fissures parallel to the subduction zone. In white, zones of largest extension. $\mathrm{E}$ is extension and $\mathrm{C}$ is compression. Black triangles are volcanoes that erupted or showed activity after the earthquakes with dates of volcanic eruption or unrest. White triangles are volcanoes with no unrest or eruption. (c) Coulomb stress changes induced by the two subduction earthquakes on the en echelon inner arc fault system (represented with a dashed black box) between Montserrat and southern Martinique. We considered that faults are normal with a slight component of left lateral motion (15\%), parallel to the trench with a dip of $50^{\circ}$ toward east. We verified that the Coulomb stress pattern is roughly the same for westward dipping faults. Modeling results are shown in vertical sections beneath the volcanic arc. Black boxes are Bouillante-Montserrat fault system (BMFS) and Saintes fault system (SFS). Black triangles are volcanoes with names MP (Mt. Pelée), DV (Desolation Valley in Dominica), SG (Soufrière of Guadeloupe), SHM (Soufrière Hills of Montserrat).

between Basse-Terre and Montserrat, where the April and May 1897 earthquakes may have occurred. The 1843 earthquake might therefore have brought the BouillanteMontserrat fault system closer to failure. The 1839 and 1843 events also contributed to increase the normal strain by more than $2.10^{-6}$ beneath all volcanoes, with the exception of the Soufrière of St. Vincent and St. Lucia (Figures 10a and 10b). The volumetric strain change is positive along the

Figure 9. Pressure and normal stress changes induced on spherical reservoir and $\mathrm{N} 70^{\circ} \mathrm{E}$ to $\mathrm{N} 140^{\circ} \mathrm{E}$ dikes or dike-shaped reservoirs by the $M_{s}=7.48$ October 1974, $M_{w}=6.3,16$ March 1985 and 21 November 2004 earthquakes on Soufrière Hills (Montserrat) and Soufrière of Guadeloupe. (a) In map view at 5 and $6 \mathrm{~km}$ depth (see text). White dots indicate volcanoes. (b) Along E-W striking cross sections beneath volcanoes. Arrows indicate closing or opening of dikes. The 8 October 1974 is modeled as a $\mathrm{N} 70^{\circ} \mathrm{E}$ striking and $50^{\circ} \mathrm{SE}$ dipping [McCann et al., 1982], $60 \mathrm{~km}-\mathrm{long}$ and $20 \mathrm{~km}-$ wide dislocation in a elastic half-space with a pure normal slip of $3 \mathrm{~m}$. The 16 March 1985 earthquake model is a N132 ${ }^{\circ} \mathrm{E}$ striking, $80^{\circ} \mathrm{N}$ dipping, $30 \mathrm{~km}$-long, $15 \mathrm{~km}$-wide, pure left lateral strike slip dislocation of $0.3 \mathrm{~m}$ with a center at $62.173^{\circ} \mathrm{W}$,

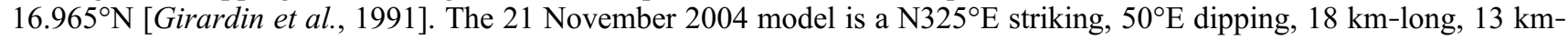
wide dislocation with a rake of $-77^{\circ}$ and a slip of $0.5 \mathrm{~m}$. 
whole arc between St. Vincent and St. Kitts. By modeling the 1843 earthquake with a smaller dislocation $(6 \mathrm{~m}$ on a 140 -km-long) in agreement with a $(M<8)$ as inferred by Bernard and Lambert [1988], the volcanoes located between Martinique and St. Kitts are also dilated but by a smaller amount. Eruptive (phreatic or magmatic), or enhanced geothermal and fumarolic activity was reported at four of the volcanoes within the 9 years following the earthquakes. The largest strain changes, beneath Mt. Pelée, Soufrière of Guadeloupe, Soufrière Hills, Nevis Peak, and Mount Lamuigua were located in regions facing the earthquake ruptures. Mt. Pelée erupted twice after the earthquakes, in 1851 and 1902, and unrest was reported in Montserrat in 1843 and 1895. Except the Soufrière of St. Vincent and St. Lucia, all the volcanoes lie within areas of dilation and expansion of dikes (increase of normal strain) or spherical reservoirs (increase of volumetric strain), respectively.

\section{Possible Triggering Mechanisms}

[48] Although not all the volcanoes responded to the stress and pressure changes caused by the earthquakes, our modeling does suggest that certain eruptions and earthquakes may be coupled through static stress transfer. In Figure 5, on the basis of our models, we indicated, by red vertical bars, which volcano may have been perturbed by static stress imparted by an earthquake. We calculated that $32 \%$ of the eruptions occurred within 3 years after a neighboring earthquake suggesting that static stress changes could be one of the main physical processes of coupling between the two phenomena in the Lesser Antilles. Expansion or compression can be advocated to account for the triggering of eruptions by static stress changes [e.g., Nostro et al., 1998; Feuillet et al., 2006; Walter and Amelung, 2007, and references therein]. An increase of pressure around a magma chamber may trigger the upward propagation of dikes from the reservoir's roof toward the surface and promote an eruption [Linde and Sacks, 1998; Hill et al., 2002]. An increase of horizontal tensile stress unclamps cracks and fissures above the magma chamber, favoring the upward opening of dikes. Expanding the magma in the conduit can further lead to bubbles formation and faster magma ascent in the volcanic column [Jaupart, 1996; Brodsky et al., 1998].

[49] Other eruptions occurred soon after an earthquake but far from the epicenter as the 1851 phreatic eruption at Mount Pelée after the 16 May 1851 earthquake in Guadeloupe. This eruption could have occurred simply by chance but other processes may be involved such as dynamic stresses that act at much larger distances and may have initiate volcanic activity beneath more distant volcanoes. As an example, seismic waves are able to induce overpressure in the magmatic plumbing system by nucleation and growth of bubbles within the magma [Manga and Brodsky, 2006]. Recent geochemical studies have shown that a magmatic intrusion may have promoted the 1976 phreatic eruption at the Soufrière [Villemant et al., 2005]. The static stress increase around this volcano after the 8 October 1974 earthquake may have been sufficient to squeeze a small volume of magma toward the surface, close to the hydrothermal system, promoting the 1976 phreatic eruption. On the other hand, the rapid response of the volcanic system, with earthquake swarms occurring within the earthquake coda, may also suggest a triggering trough dynamic stress changes.

[50] The time lag between the triggering processes and the unrest or eruption at volcano can reach several years [Nostro et al., 1998] and could be explain by the state of magmatic overpressure within the conduit [e.g., Watt et al., 2009, and reference therein]. Eruptions within days of a large earthquake likely occur at volcanoes that have reached a critical overpressure state whereas longer responses could be observed at volcanoes, bellow the critical point, but where the earthquake-induced stress changes can be large enough to have initiate the eruptive process. At Soufrière Hills, the 1985 earthquake was followed by a growing rate of seismicity beneath the volcano until the eruption beginning in 1995. By compressing its plumbing system by more than $0.05 \mathrm{MPa}$, the earthquake could have been sufficient to open the path to the eruption by squeezing new batches of magma into superficial reservoirs. Following the 21 November 2004 Saintes earthquake, the Soufrière of Guadeloupe was subjected to slight additional extension. The static normal stress changes induced by the 2004 earthquake, though small, contributed to open $\mathrm{N} 140^{\circ} \mathrm{E}$-trending dikes and fissures beneath the dome. But, although such extension might be expected to open magma or hydrothermal pathways, no evidence of increased activity has been noted thus far.

\section{Montserrat Ongoing Eruption}

[51] Toda et al. [2002] have shown that dike opening at Izu island promoted $M \geq 6$ strike-slip earthquakes, tens of kilometers from the volcano. In Djibouti, Jacques et al. [1996] showed that the distribution of the seismicity recorded for several months after the 1978 eruption in the Asal rift may be explained by the pattern of Coulomb stress perturbations generated by the opening of eruptive dikes. In Italy, the seismic swarms at Alban Hills may be promoted by stress changes induced by pressure changes under the volcano [Feuillet et al., 2004b]. Here we seek to understand the distribution of the early seismicity recorded at the beginning of the Soufrière Hills eruption in relation with volcanotectonic stresses.

\subsection{Soufrière Hills Seismicity}

[52] The Soufrière Hills volcano belongs to a series of young domes (>200 kyr [Harford et al., 2002]) aligned along a $\mathrm{N} 120^{\circ} \mathrm{E}$ trend and emplaced along a fissure set parallel to the en echelon normal fault system of BouillanteMontserrat [Feuillet et al., 2010] (Figure 11). The distribution of early seismicity recorded beneath Montserrat between 28 July 1995 (10 days after the eruption beginning) and November 1996, before the first June 1997 large dome collapse [Aspinall et al., 1998] shows clear coupling between the latter faults and the volcanic processes at Soufrière Hills volcano. The seismicity occurred in an ENEWSW-elongated zone, parallel to faults, under the Quaternary domes and has migrated through time [Aspinall et al., 1998]. During the first 2 months, most earthquakes clustered at depth ranging between 2 and $5 \mathrm{~km}$ under St. George's Hills. Between October 1995 and July 1996, they were 


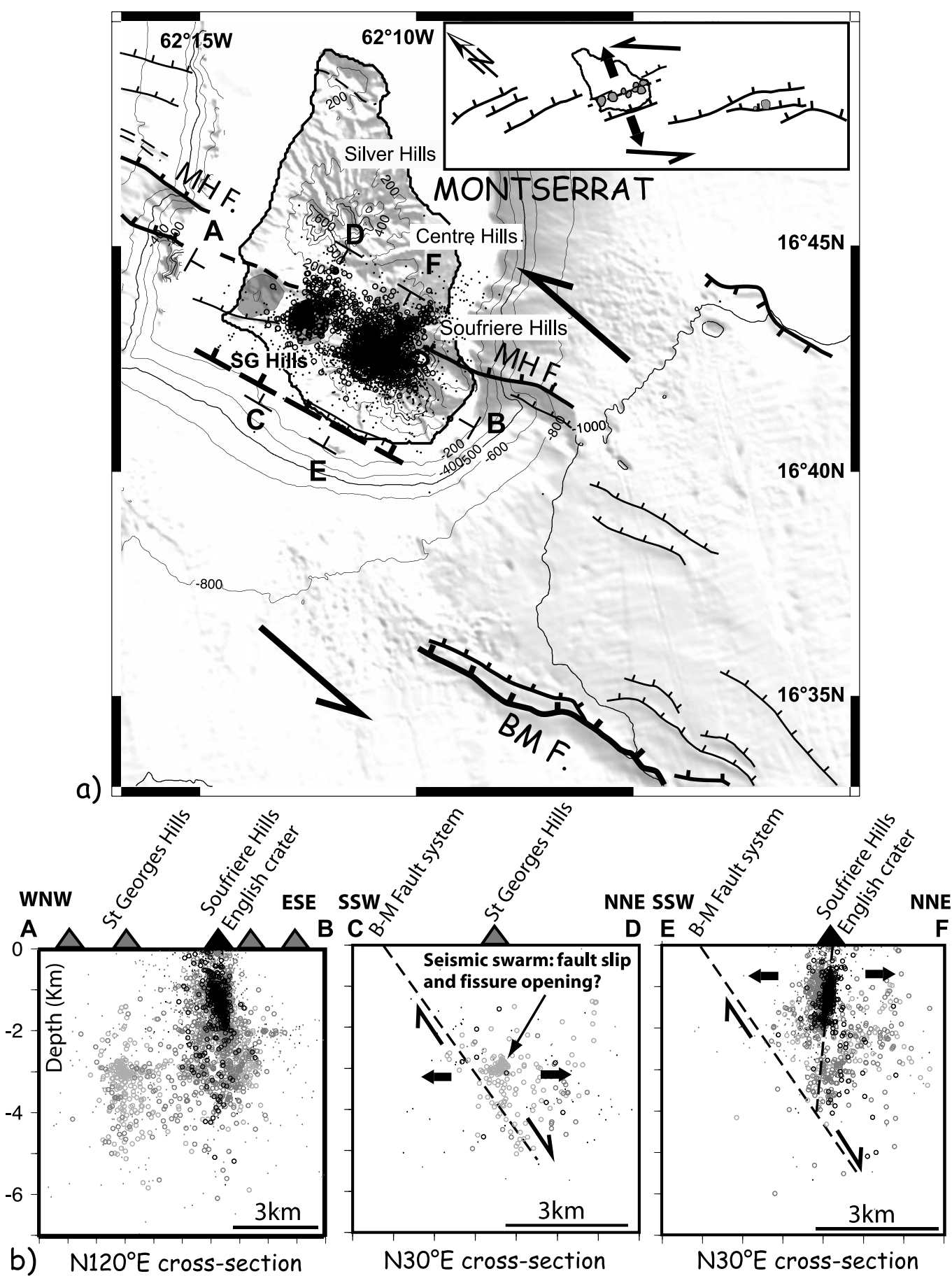

Figure 11. (a) Active faults and 1995-1996 seismicity in Montserrat (faults from Feuillet [2000] and Feuillet et al. [2004a, 2010] and this study and seismicity from Mattioli et al. [1998]). Shaded bathymetry from AGUADOMAR 1999 cruise data. Topography in Montserrat was provided by Professor Geoff Wadge. Volcanic domes in gray. Inset is the simplified tectonic model. The southern part of Montserrat, where lies the active volcano of Soufrière Hills is crosscut by the Bouillante-Montserrat fault system. We infer that the most recent volcanic domes $(<200 \mathrm{kyr}$, in gray) emplaced along a fault-parallel fissure opened in the fault system hanging wall. Active faults are arranged in right stepping echelon and accommodate a left lateral motion along the volcanic arc. SG Hills is St. Georges Hills. (b) Fault parallel or perpendicular cross sections beneath the alignment of volcanic domes. Light gray, earthquakes recorded between 28 July and 30 September 1995. Dark gray indicates earthquakes recorded between October 1995 and June 1996. In black are earthquakes localized between July 1996 and 29 October 1996. The latter swarm seams underlined $\mathrm{a} \approx 1 \mathrm{~km}^{2}$ ESE-WNW striking and $85^{\circ} \mathrm{S}$ dipping dike located beneath the English crater at depth of about 0.5 to $1 \mathrm{~km}$. Opening of such a dike by $1 \mathrm{~m}$ was also inferred by GPS data modeling [Mattioli et al., 1998]. 


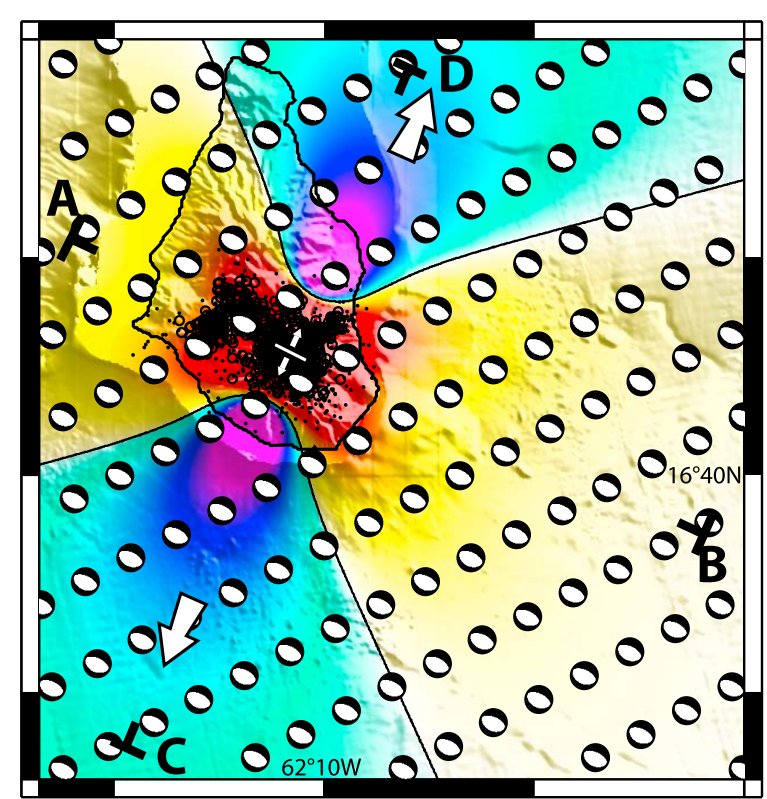

a)

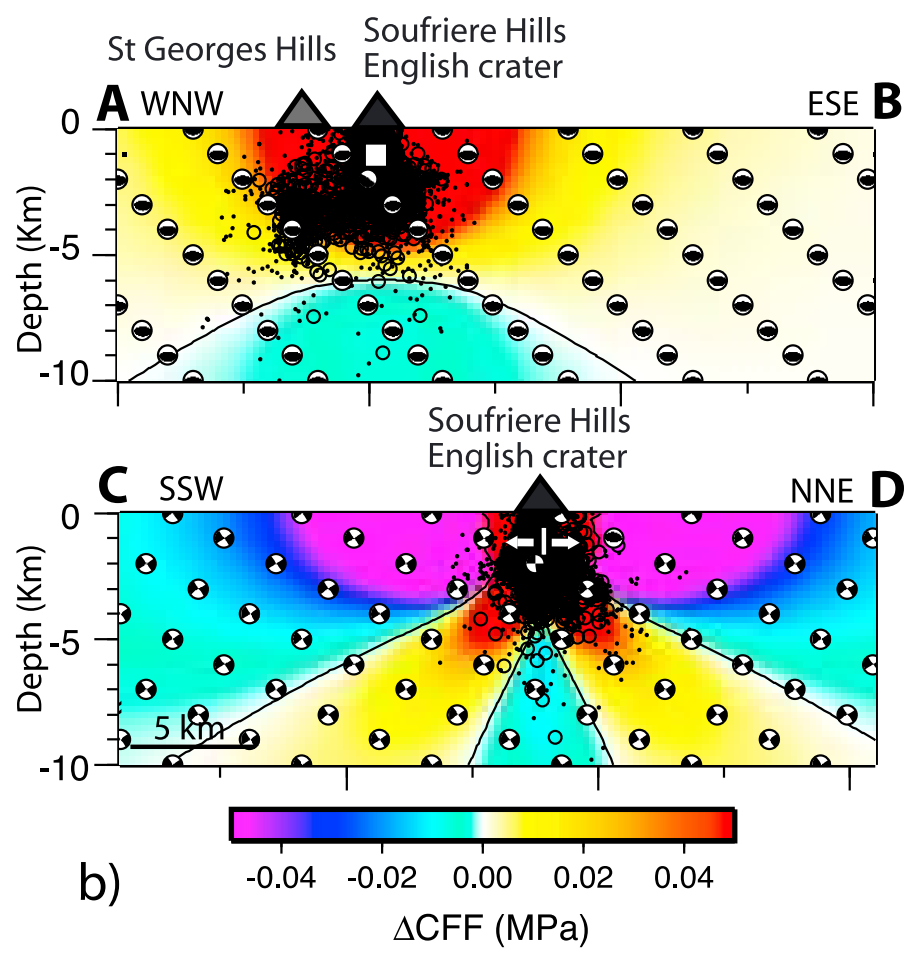

Figure 12. Coulomb stress transferred by opening of $1 \mathrm{~m}$ of a $1 \mathrm{~km}^{2}$ eruptive dike located at $0.7 \mathrm{~km}$ under the Soufrière Hills volcano (similar to that proposed by Mattioli et al. [1998], on the basis of 1995-1996 GPS data inversion) on surrounding faults (a) in map at $3 \mathrm{~km}$-depth and (b) along N115 and $\mathrm{N} 25^{\circ} \mathrm{E}$ cross sections beneath Soufrière Hills. Stress changes are calculated on optimally oriented planes in the total stress, a preexisting extensional stress with $\sigma_{3}$ horizontal oriented $\mathrm{N} 25^{\circ} \mathrm{E}$ plus the stress related to the opening of dike. Earthquakes as in Figure 11, all earthquakes are located in red zones where the Coulomb stress increased by more than $0.04 \mathrm{MPa}$ (see text).

spread within a large volume under Soufrière Hills, between the surface and $5 \mathrm{~km}$ depth. During the last months of observation, however, they clustered more tightly at a shallower depth $(<2 \mathrm{~km})$. Since the end of 1996, all volcano-tectonic earthquakes are localized beneath the English Crater, between 0 and $7 \mathrm{~km}$ depth (MVO reports). Fault perpendicular cross sections, beneath the St. George's Hills, show that some earthquakes underline a $50^{\circ}$ northward dipping fault plane that may intersect the seafloor along the southern shore of Montserrat. This fault probably marks the northward continuation of the Bouillante-Montserrat rightsteeping an echelon array (Figure 11, inset). Other earthquakes occurred in the fault hanging wall, in a small volume, at $3 \mathrm{~km}$ depth beneath the St. George's Hills dome. Under the English Crater, between 0 and $2 \mathrm{~km}$ depth, the seismicity clearly underlined a steeply south dipping plane trending WNW-ESE, which might correspond to a feeder dike. Such a dike might in turn belong to a larger fissure system connected to the fault at depth and crossing its hanging wall. Below, we show that the distribution of the early seismicity may be accounted for by calculating the Coulomb stress changes induced by volcanic processes on surrounding faults.

\subsection{Coulomb Stress Modeling}

[53] Static Coulomb stress changes (or variation in Coulomb Failure Function (CFF)) caused by volcanic pro- cesses on neighboring faults [Harris, 1998; King and Cocco, 2001] are calculated by using the equation:

$$
\Delta C F F=\Delta \tau+\mu^{\prime} \Delta \sigma_{n}
$$

where $\Delta \tau$ is the shear stress change computed in the direction of slip on the faults, $\Delta \sigma_{n}$ is the normal stress change (positive for extension), and $\mu^{\prime}$ is the effective coefficient of friction. Dike opening (closing) or pressure changes are modeled as planar dislocations in an elastic homogeneous half-space [Okada, 1992]. An increase of pressure in a spherical source or the opening of a sill or a dike approximates the magma injection. Opening of three orthogonal dikes, intersecting in their center, simulates the expansion of a spherical magma chamber approximating the Mogi [1958] point source [e.g., Feuillet et al., 2004b]. Lamé's coefficients are equal to $32 \mathrm{GPa}$.

[54] The early seismicity recorded in Montserrat extended several kilometers from the Soufrière Hills volcano, beneath St. George's Hills (Figure 11). The Coulomb stress changes resulting from the $1 \mathrm{~m}$ opening of a WNW-ESE striking $1 \mathrm{~km}^{2}$ dike, $0.7 \mathrm{~km}$ under the English Crater [Mattioli et al., 1998], within a regional least principal stress $\sigma_{3}$ oriented $\mathrm{N} 25^{\circ} \mathrm{E}$, in agreement with the active faulting geometry and alignment of volcanic domes [Feuillet et al., 2010], account for the particular distribution of earthquakes (Figure 12). Almost all events are located in red zones where the Coulomb stress increased by more than $0.04 \mathrm{MPa}$. No earthquakes 


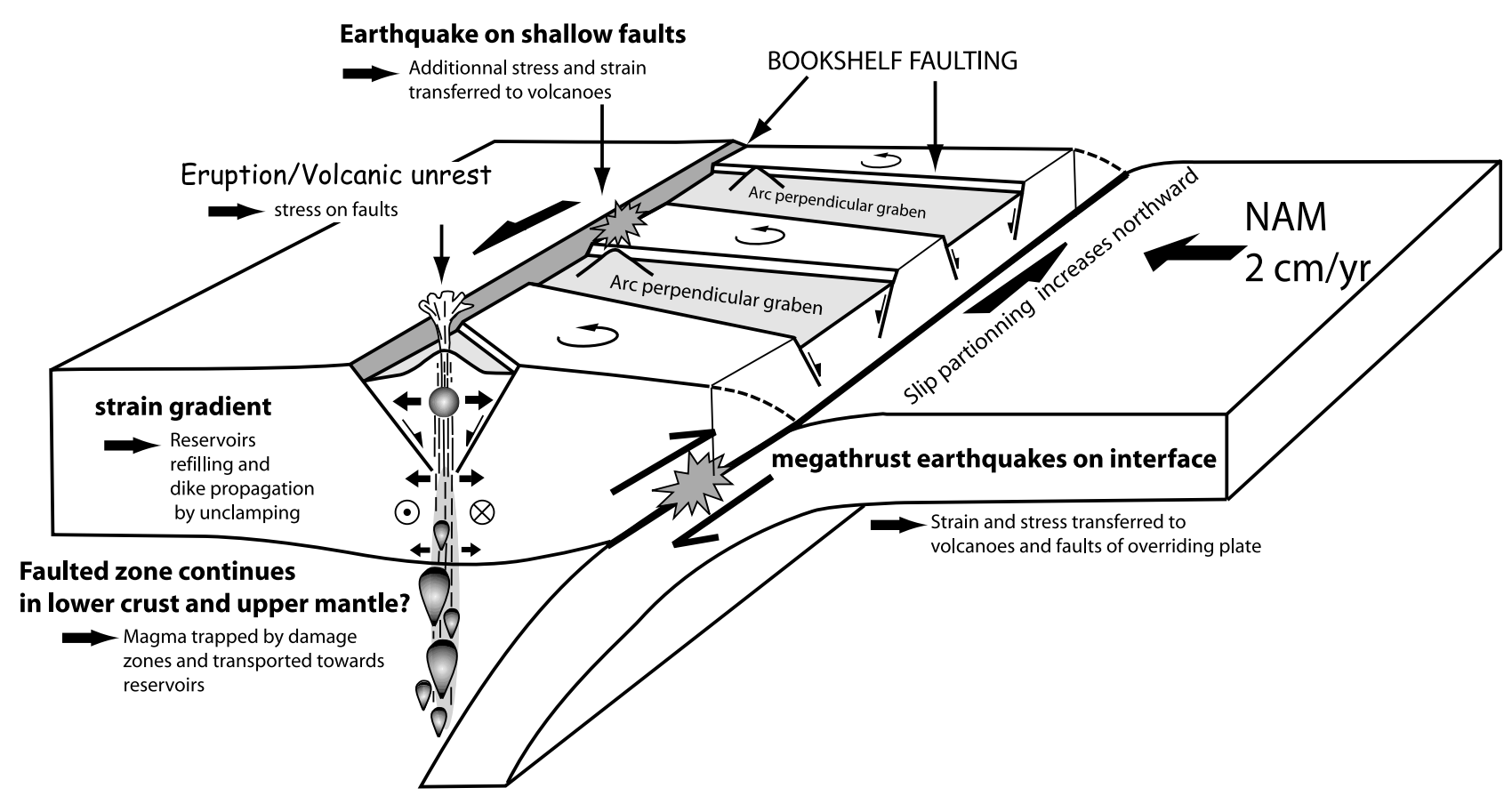

Figure 13. Sketch showing the possible interactions between intraplate and interplate earthquakes and volcanoes. The large interplate (megathrust) events increase the Coulomb stress on the inner arc shallow faults and promote a strain gradient favoring the upward propagation of magma toward reservoirs and/or earth surface. This may encourage earthquake on shallow faults and eruptions or unrests of the neighboring volcanoes. The shallow earthquakes induce additional stress or strain around volcanoes. Slip partitioning induced bookshelf faulting in the overriding Caribbean plate (see text). NAM is North American plate.

were recorded deeper than $7 \mathrm{~km}$ beneath the fissure system (Figure 12b), in the zone where the Coulomb stress decreased. Under the Soufrière Hills, the seismic swarms were restricted to zones of maximum stress increase. No event occurred in areas of maximum stress decrease. In Figure 12, we show the predicted focal mechanism associated to one of the optimal oriented plane for Coulomb failure in the preexisting regional stress field (OOP). Such planes are calculated in the total stress (preexisting regional stress plus the stress induced by the opening of dike [ King and Cocco, 2001]). As expected, far away from the dike, the regional stress dominated and the fault plane solution are all compatibles with a $\mathrm{N} 25^{\circ} \mathrm{E}$ extension. Close to the dike, however, the stress induced by the dike opening dominates and predicted faults planes solution can be heterogeneous (Figure 12b). The results suggest that the seismicity recorded under St. Georges Hills between July and September 1995 was related to slip along faults of the Bouillante-Montserrat system that was brought to failure by the opening of an eruptive dike, beneath the English crater. Other seismic sequences associated with hot spring activity and inflation of the volcano occurred in the southern part of Montserrat in 1933-1937 and 1966-1967 [Shepherd et al., 2002]. Between 1933 and 1937, more than 3000 earthquakes were felt, most of them located beneath St. George's Hills. We calculate that inflation of a spherical or dike-shaped reservoir in an extensional regional stress strongly increase the Coulomb stress beneath St. George's Hills. The 1933-1937 and 1966-1967 sequences may be related to episodic refilling of magmatic reservoirs beneath the Soufrière Hills volcano. Such volcanic processes (dike injection of reservoir refilling) may induce stress changes several tens of kilometers away from a volcano, promoting regional earthquakes. For instance, the 10 November $1935, M>6$ earthquake, during the 1933-1937 sequence, may have been promoted by reservoir pressure increase beneath the volcano.

\section{Summary and Conclusions}

[55] On the basis of improve knowledge of active faulting in the Lesser Antilles and by using of a regional attenuation law, we reexamined the source of historical seismicity reported between 1690 and 2009. Several superficial $M>6$ earthquakes have occurred north of Guadeloupe along a large en echelon fault system that crosses the inner edge of the Lesser Antilles arc between Nevis and Martinique. Some were followed by unrest or eruptions at neighboring volcano suggesting a link between the two phenomena. We calculated that the most recent intraplate earthquakes have increase the static stress beneath the volcanoes plumbing system and may have promote eruptions and seismic activity beneath volcanic complexes. The en echelon fault system is clearly an important locus of active intraplate deformation, distinct from the subduction interface (Figure 13). This system appears to accommodate part of the oblique convergence between Caribbean and North American plates. Since the trench parallel component of shear increases northwestward, slip rates along the inner arc faults should increase northward, where large to moderate earthquakes indeed seem to be more frequent (Figure 1). Our modeling suggests that the megathrust earthquakes of 1839 and 1843 increased the Coulomb stress along the shallow intraplate fault systems, triggering earth- 

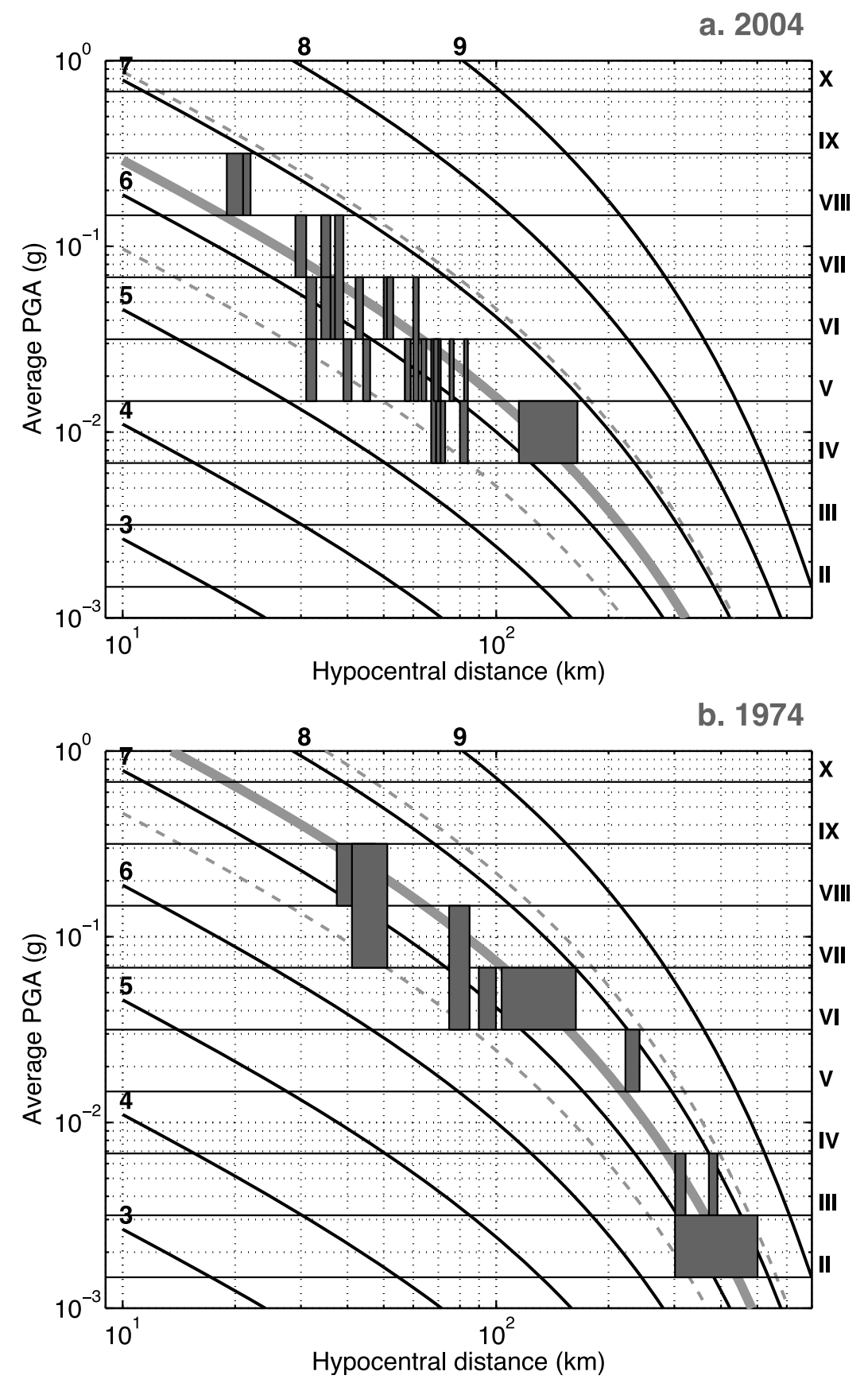

Figure A1. $B^{3}$ attenuation law [Beauducel et al., 2004, 2011]. Average PGA (in g) versus hypocentral distance (in km), magnitude, and corresponding intensities (MSK scale) [Gutenberg and Richter, 1942]. Solid black curves stand for magnitudes levels and horizontal solid lines stand for intensities limits. We also report intensity observations and prediction for some earthquakes; gray thick and dashed curves stand for PGA prediction and uncertainties (a factor of 3). (a) The 21 November 2004 earthquake $(M=6.3$, intensities after Cara et al. [2005]); (b) 8 October 1974 earthquake ( $M=7.4$, intensities after Feuillard [1985] and Tomblin and Aspinall [1975]).

quakes on them. The 29 February 1897 earthquake, in particular, may have ruptured the Bouillante-Montserrat fault, upon which the 1843 earthquake imparted the largest Coulomb stress increase. As a result of slip partitioning, the inner arc active fault zone likely extends down into the lower crust and upper mantle [Bowman et al., 2003], contributing to extract magma ponded above the subduction interface
(Figure 13). We calculated that megathrust earthquakes can generate an extensional strain field increasing from the base of the crust toward the surface along the volcanic arc. This may help unclamp inner arc faults and fissures and foster the propagation of dikes toward the surface through hydrofracturing. Moreover, the normal stress gradient would ease the ascension of magma and volatiles toward the surface. 
This might lead to volcanic eruption and/or to reservoir recharge rate increase. Conversely, the volcanic processes induce Coulomb stress increase that may bring closer to rupture the neighboring faults as observed in Montserrat southern part in 1995-1996. Though complex, the particular tectonic framework of the lesser Antilles arc may in fact be ideal to further explore time correlations between megathrust earthquakes, shallow intraplates events, and volcanic eruptions or geothermal bursts.

\section{Appendix A: Regional Attenuation Law for Seismic Intensities}

[56] The regional attenuation law for intensities (fully described by Beauducel et al. [2004, 2011] combines a seismic attenuation law for peak ground accelerations (PGA) with classical empirical relation between intensities and accelerations. The PGA attenuation law takes its simplest form:

$$
\log (P G A)=a M+b R-\log (R)+c
$$

where $P G A$ is the horizontal acceleration peak (in g), $M$ is the magnitude, $R$ is the hypocentral distance (in $\mathrm{km}$ ), and $a, b, c$ are parameters. These have been adjusted using seismic data recorded at 12 strong motion permanent stations, with mixed site conditions, rock and soil [Beauducel et al., 2004, 2005; Bengoubou-Valerius et al., 2008], in the period 21 November to 27 December 2004. The data set includes about 400 earthquakes corresponding to 1430 values of recorded PGA, with magnitudes ranging from 1.1 to 6.3 , distances from 2 to $450 \mathrm{~km}$, and PGA from $16 \mu \mathrm{g}$ to $0.36 \mathrm{~g}$. These correspond to Les Saintes main shock $M_{w}=6.3$ and mostly the associated aftershocks but also some regional events of various magnitudes, locations, and depths. The final best model, $a=0.6210$, $b=-0.003453, c=-3.375$, produces a PGA RMS-misfit equal to a factor of $3\left(\log _{10}(R M S) \approx 0.5\right.$, usual in the literature for attenuation laws), a value which corresponds also to the difference between rock and soil conditions in the observed PGA [Bengoubou-Valerius et al., 2008].

[57] As suggested by Feuillard [1985] for the Lesser Antilles, the regional law uses the empirical relation between accelerations and intensities from Gutenberg and Richter [1942]:

$$
I=3 \log (P G A)+3 / 2
$$

where $I$ is the mean intensity (MSK scale), PGA is acceleration (in $\mathrm{cm} \cdot \mathrm{s}^{-2} \approx \mathrm{mg}$ ). Following equation (3), the uncertainty on our predicted PGA, a factor of 3 , implies an error on $I$ equal to 1.4. The final law has been named $B^{3}$ (from initials of the three authors) and is presented in Figure A1. Since 2005, the law is used to produce routine theoretical shake maps at Guadeloupe and Martinique observatories and has been permanently controlled for the last years of seismic monitoring in the region. Comparisons between observations and the law lead to an average uncertainty on predicted intensities of \pm 1 degree in the MSK scale [Beauducel et al., 2011].

[58] The intensity law fits very well the 21 November 2004 main shock's reported intensities (maximum of VIII [Cara et al., 2005], see Figure A1a and maps of Figures $2 \mathrm{j}$ and 31), as well as the intensities (from II to VI) of hundreds of aftershocks estimated thanks to Guadeloupe inhabitants' testimonies during the 4 years of the following seismic sequence [Beauducel et al., 2005, 2011]. The law also fits the reported intensities of the 8 October 1974, $M=$ 7.4 earthquake, even for long distance observations up to $400 \mathrm{~km}$ (see Figures A1b, 2h, and 3j). This makes us confident about the feasibility of using this law for historical earthquake of magnitudes greater than 6 and possibly up to 8 by extrapolation.

[59] Acknowledgments. We thank the French Institut National des Sciences de 1'Univers (CNRS) and Institut de Physique du Globe de Paris for financial support. Our thanks also go to Willy Aspinall and Geoff Wadge for providing us with seismic and topographic data from Montserrat. The local attenuation law was calculated using data from stations of the Permanent Accelerometer Network (GIS-RAP), installed and maintained by the Guadeloupe observatory staff (OVSG-IPGP). We are grateful to Ross S. Stein and two anonymous reviewers for helpful suggestions that helped to significantly improve an earlier version of this paper. IPGP contribution 3191.

\section{References}

Aspinall, W. P., A. D. Miller, L. L. Lynch, J. L. Latchman, R. C. Stewart, R. A. White, and J. A. Power (1998), Soufrière Hills eruption, Montserrat, 1995-1997: Volcanic earthquake locations and fault plane solutions, Geophys. Res. Lett., 25(18), 3397-3400.

Bangs, N. L., G. L. Christeson, and T. H. Shipley (2003), Structure of the Lesser Antilles subduction zone backstop and its role in a large accretionary system, J. Geophys. Res., 108(B7), 2358, doi:10.1029/2002JB002040.

Barrientos, S. E. (1994), Large thrust earthquakes and volcanic eruptions, Pure Appl. Geophys., 142, 225-237.

Bautista, B. C., L. P. Bautista, E. S. Barcelona, R. S. Punongbayan, E. P. Laguerta, A. R. Rasdas, G. Ambubuyog, E. Q. Amin, and R. S. Stein (1996), Relationship of regional and local structures to Mount Pinatubo activity, in The 1991-1992 Eruptions of Mount Pinatubo, edited by R. S. Punongbayan and C. G. Newhall, pp. 351-370, Univ. of Wash. Press, Seattle, Wash.

Bazin, S., et al. (2005), Volcano-seismic signals and monitoring network on La Soufriere of Guadeloupe, paper presented at Soufriere Hills Volcano-Ten Years On International Workshop, Int. Assoc. for Volcanol. and Chem., Little Bay, Montserrat.

Bazin, S., N. Feuillet, M.-P. Bouin, C. Duclos, M. Bengoubou-Valerius, and J.-B. de Chabalier (2008), The $\mathrm{Mw}=7.4$ Martinique (Lesser Antilles) intermediate depth earthquake of November 29, 2007: A first analyse, paper presented at 18th Caribbean Geological Conference, Soc. Dominicana de Geol., Santo Domingo, Dominican Republic.

Bazin, S., N. Feuillet, C. Duclos, W. Crawford, A. Nercessian, M. BengoubouValerius, F. Beauducel, and S. C. Singh (2010), Seismicity and tomographic modelling of Les Saintes (FWI) seismic sequence using ocean bottom seismometers, Tectonophysics, 489(1-4), 91-103.

Beauducel, F., and P. Besson (2008), The review of the 1975-1977 eruption of La Soufrière de Guadeloupe (FWI), Eos Trans. AGU, 89(53), Fall Meet. Suppl., Abstract V44A-03.

Beauducel, F., S. Bazin, and M. Bengoubou-Valerius (2004), Loi d'atténuation B-cube pour l'évaluation rapide des intensités sismiques probables dans l'archipel de Guadeloupe, report, Inst. de Phys. du Globe de Paris, Gourbeyre, France. [Available at http://www.ipgp.fr/beaudu/download/ 2004BeauducelB3.pdf.]

Beauducel, F., et al. (2005), The Mw 6.3 earthquake of Les Saintes (Guadeloupe) on November 21, 2004, paper presented at European Seismological Commission Annual Workshop, IAVCEI, Saint-Claude, Guadeloupe.

Beauducel, F., et al. (2011), Empirical model for rapid macroseismic intensities prediction in Guadeloupe and Martinique, C. R. Geosci., in press.

Beck, C., N. Feuillet, J.-L. Reyss, and the GWADASEIS Scientific Party (2009), Pleistocene to recent sedimentary imprints of seismo-tectonic activity in Lessers Antilles; Preliminary results from GWADASEIS coring campaign, 12éme Congrès Français de Sédimentologie, Assoc. des Sédiment. Fr., France 25-31 Oct.

Bengoubou-Valerius, M., S. Bazin, D. Bertil, F. Beauducel, and A. Bosson (2008), CDSA: A new seismological data center for the French Lesser Antilles, Seismol. Res. Lett., 79(1), 90-102.

Bernard, P., and J. Lambert (1988), Subduction and seismic hazard in the northern Lesser Antilles-Revision of the historical seismicity, Bull. Seismol. Soc. Am., 78(6), 1965-1983.

Boudon, G., A. Le Friant, B. Villemant, and J. P. Viodé (2005), Martinique, in Volcanic Hazard Atlas of the Lesser Antilles, edited by M. Lindsay et al., 
pp. 127-146, Univ. of the West Indies, St. Augustine, Trinidad and Tobago.

Boudon, G., J.-C. Komorowski, B. Villemant, and M. P. Semet (2008), A new scenario for the last magmatic eruption of La Soufrière of Guadeloupe (Lesser Antilles) in 1530 A.D.: Evidence from stratigraphy radiocarbon dating and magmatic evolution of erupted products, J. Volcanol. Geotherm. Res., 178(3), 474-490.

Bowin, C. (1976), Caribbean gravity field and plate tectonics, Spec. Pap. Geol. Soc. Am, 169, 1-79.

Bowman, D., G. King, and P. Tapponnier (2003), Slip partitioning by elastoplastic propagation of oblique slip at depth, Science, 300(5622), 1121-1123.

Brodsky, E. E., B. Sturtevant, and H. Kanamori (1998), Earthquakes, volcanoes, and rectified diffusion, J. Geophys. Res., 103(23), 23,827-23,838.

Capadose, H. (1845), Sixteen Years in the West Indies, Newby, London.

Cara, M., D. Bertil, N. Feuillet, E. Jacques, P. Tapponnier, P. Guéguen, M. Bengoubou-Valérius, C. Sira, B. Lebrun, and F. Beauducel (2005), Séisme des Saintes (Guadeloupe) du 21 novembre 2004, Note Prelim. $B C S F 2005-N P 3$, Bur. Cent. Sismol. Franais, Strasbourg, France.

Dorel, J. (1981), Seismicity and seismic gap in the Lesser Antilles arc and earthquake hazard in Guadeloupe, Geophys. J. R. Astron. Soc., 67, 679-695.

Dziewonski, A. M., G. G. Ekstrom, and N. N. Maternovskaya (2000), Centroid-moment tensor solutions for October-December, 1999, Phys. Earth Planet. Inter., 121, 205-221.

Feuillard, M. (1985), Macrosismicité de la Guadeloupe et de la Martinique, 348 pp., Inst. de Phys. du Globe de Paris, Paris.

Feuillet, N. (2000), Sismotectonique des Petites Antilles. Liaison entre activité sismique et volcanique, doctorate thesis, 283 pp., Univ. Paris VII, Paris.

Feuillet, N., I. Manighetti, and P. Tapponnier (2001), Active arc-transverse normal faulting in guadeloupe (French lesser antilles), C. R. Acad. Sci. Ser. IIa, 333(9), 583-590.

Feuillet, N., I. Manighetti, P. Tapponnier, and E. Jacques (2002), Arc parallel extension and localization of volcanic complexes in Guadeloupe, Lesser Antilles, J. Geophys. Res., 107(B12), 2331, doi:10.1029/2001JB000308.

Feuillet, N., P. Tapponnier, I. Manighetti, B. Villemant, and G. C. P. King (2004a), Differential uplift and tilt of Pleistocene reef platforms and Quaternary slip rate on the Morne-Piton normal fault (Guadeloupe, French West Indies), J. Geophys. Res., 109, B02404, doi:10.1029/2003JB002496.

Feuillet, N., C. Nostro, C. Chiarabba, and M. Cocco (2004b), Coupling between earthquake swarms and volcanic unrest at the Alban Hills Volcano (central Italy) modeled through elastic stress transfer, J. Geophys. Res., 109, B02308, doi:10.1029/2003JB002419.

Feuillet, N., M. Cocco, C. Musumeci, and C. Nostro (2006), Stress interaction between seismic and volcanic activity at Mt Etna, Geophys. J. Int., 164 (3), 697-718

Feuillet, N., et al. (2010), Active faulting induced by slip partitioning in Montserrat and link with volcanic activity: New insights from the 2009 GWADASEIS marine cruise data, Geophys. Res. Lett., 37, L00E15, doi:10.1029/2010GL042556.

Feuillet, N., F. Beauducel, E. Jacques, P. Tapponnier, B. Delouis, S. Bazin, M. Vallée, and G. C. P. King (2011), The $\mathrm{Mw}=6.3$, November 21, 2004, Les Saintes earthquake (Guadeloupe): Tectonic setting, slip model and static stress changes, J. Geophys. Res., doi:10.1029/2011JB008310, in press.

Girardin, N., M. Feuillard, and J. P. Viode (1991), Regional seismic network in the Lesser Antilles Arc-Shallow seismicity (1981-1988), Bull. Soc. Geol. Fr., 162(6), 1003-1015.

Gutenberg, B., and C. F. Richter (1942), Earthquake magnitude, intensity, energy, and acceleration, Bull. Seismol. Soc. Am., 32(3), 163-191.

Gutenberg, B., and C. F. Richter (1954), Seismicity of the Earth and Associated Phenomena, Princeton Univ. Press, Princeton, N. J.

Harford, C. L., M. S. Pringle, R. S. J. Sparks, and S. R. Young (2002), The volcanic evolution of Montserrat using 40Ar/39Ar geochronology, in The Eruption of Soufrière Hills Volcano, Montserrat, From 1995 to 1999 , edited by T. H. Druitt and B. P. Kokelaar, pp. 93-113, Geol. Soc. of London, London.

Harris, R. A. (1998), Introduction to special section: Stress triggers, stress shadows, and implications for seismic hazard, J. Geophys. Res., 103(B10), 24,347-24,358.

Hill, D. P., F. Pollitz, and C. Newhall (2002), Earthquake-volcano interactions, Phys. Today, 55(11), 41-47.

Hincks, T., R. S. J. Sparks, P. Dunkley, and P. Cole (2005), Montserrat, in Volcanic Hazard Atlas of the Lesser Antilles, edited by M. Lindsay et al., pp. 147-168, Univ. of the West Indies, St. Augustine, Trinidad and Tobago.

Institut de Physique du Globe de Paris (IPGP) (2008), Bilan mensue de l'activité volcanique de la Soufrière de Guadeloupe et de la sismicité régionale, report, Gourbeyre, France. [Available at http://www.ipgp.fr/ pages/0303040901.php.]

Jacques, E., G. C. P. King, P. Tapponnier, J. C. Ruegg, and I. Manighetti (1996), Seismic triggering by stress change after the 1978 events in the Asal Rift, Djibouti, Geophys. Res. Lett., 23(18), 2481-2484.

Jaupart, C. (1996), Physical models of volcanic eruptions, Chem. Geol. $128,217-227$

King, G. C. P., and M. Cocco (2001), Fault interaction by elastic stress changes: New clues from earthquake sequences, Adv. Geophys., 44, 1-38 Kasahara, J. (2002), Tides, earthquakes, and volcanoes, Science, 297, 348 Komorowski, J.-C., G. Boudon, M. Semet, F. Beauducel, C. AnténorHabazac, S. Bazin, and G. Hammouya (2005), Guadeloupe, in Volcanic Hazard Atlas of the Lesser Antilles, edited by J. Lindsay et al., pp. 65-102, Univ. of the West Indies, St. Augustine, Trinidad and Tobago.

Leclerc, F. (2009), Partitionnement de la convergence et fonctionnement des failles actives le long de l'arc volcanique Antillais: Apport des nouvelles données de la campagne à la mer GWADASEIS, Master Rep. 1 , 28 pp., Inst. de Phys. du Globe de Paris, Paris.

Linde, A. T., and I. S. Sacks (1998), Triggering of volcanic eruptions, Nature, 395, 888-890.

Lindsay, M. J. (2005), Saint Lucia, in Volcanic Hazard Atlas of the Lesser Antilles, edited by M. Lindsay et al., pp. 218-239, Univ. of the West Indies, St. Augustine, Trinidad and Tobago.

Lindsay, M. J., A. L. Smith, M. J. Roobolt, and M. V. Stasiuk (2005), Dominica, in Volcanic Hazard Atlas of the Lesser Antilles, edited by M. Lindsay et al., pp. 1-48, Univ. of the West Indies, St. Augustine, Trinidad and Tobago.

Lopez, A. M., S. Stein, T. Dixon, G. Sella, E. Calais, P. Jansma, J. Weber, and P. LaFemina (2006), Is there a northern Lesser Antilles forearc block?, Geophys. Res. Lett., 33, L07313, doi:10.1029/2005GL025293.

Manga, M., and E. E. Brodsky (2006), Seismic triggering of eruptions in the far field: Volcanoes and geysers, Annu. Rev. Earth Planet. Sci., 34, 263-291.

Marzocchi, W. (2002), Remote seismic influence on large explosive eruptions, J. Geophys. Res., 107(B1), 2018, doi:10.1029/2001JB000307.

Mattioli, G. S., T. H. Dixon, F. Farina, E. S. Howell, P. E. Jansma, and A. L. Smith (1998), GPS measurement of surface deformation around Soufrière Hills Volcano, Montserrat from October 1995 to July 1996, Geophys. Res. Lett., 25(18), 3417-3420.

McCann, W. R., J. W. Dewey, A. J. Murphy, and S. T. Harding (1982) A large normal-fault earthquake in the overriding wedge of the Lesser Antilles subduction zone: The earthquake of 8 October 1974, Bull. Seismol. Soc. Am., 72, 251-262.

Mogi, K. (1958), Relations between eruptions of various volcanoes and the deformation of the ground surface around them, Bull. Earthquake Res. Inst. Univ. Tokyo, 36, 99-134.

Nostro, C., R. S. Stein, M. Cocco, M. E. Belardinelli, and W. Marzocchi (1998), Two-way coupling between Vesuvius eruptions and southern Apennine earthquakes, Italy, by elastic stress transfer, J. Geophys. Res., 103(B10), 24,487-24,504.

Okada, Y. (1992), Internal deformation due to shear and tensile faults in a half-space, Bull. Seismol. Soc. Am., 82, 1018-1040.

Perrey, A. (1847), Sur les tremblements de terre des Antilles, Mem. Acad. Sci. Arts B. L. Dijon, 1845-1846, 325-392.

Perret, F. A. (1939), The Volcano-Seismic Crisis at Montserrat 1933-1937, 76 pp., Carnegie Inst., Washington, D. C.

Reid, H. F., and S. Taber (1920), The Virgin Islands earthquakes of 1867 1868, Bull. Seismol. Soc. Am., 10, 9-30.

Robertson, R. (2005a), St. Kitts, in Volcanic Hazard Atlas of the Lesser Antilles, edited by M. Lindsay et al., pp. 204-217, Univ. of the West Indies, St. Augustine, Trinidad and Tobago.

Robertson, R. (2005b), St. Vincent, in Volcanic Hazard Atlas of the Lesser Antilles, edited by M. Lindsay et al., pp. 240-261, Univ. of the West Indies, St. Augustine, Trinidad and Tobago.

Robson, G. R. (1964), An earthquake catalogue for the eastern Caribbean, Bull. Seismol. Soc. Am., 54, 785-832.

Robson, G. R., K. G. Barr, and G. W. Smith (1962), Earthquake series in St. Kitts-Nevis 1961-1962, Nature, 195(4845), 972-974.

Roux, E. (2007), Reconnaissance de la structure sismique de la zone de subduction des Petites Antilles, doctorate thesis, Univ. Paris VII, Paris.

Sainte-Claire Deville, C. (1843), Observations sur le tremblement de terre éprouvé à la Guadeloupe le 8 Février 1843, Imprimerie du Gouverneur, Basse-Terre.

Shepherd, J. B. (1992), Comment on "Subduction and seismic hazard in the Lesser Antilles" by Pascal Bernard and Jérôme Lambert, Bull. Seismol. Soc. Am., 82(3), 1534-1543

Shepherd, J. B., R. Robertson, J. Latchman, and L. Lynch (2002), Precursory activity to the 1995 eruption of the Soufrière Hills volcano, Montserrat, 
report, 19 pp., Univ. of the West Indies, St. Augustine, Trinidad and Tobago.

Simpson, K. (2005), Nevis, in Volcanic Hazard Atlas of the Lesser Antilles, edited by M. Lindsay et al., pp. 169-178, Univ. of the West Indies, St. Augustine, Trinidad and Tobago.

Stein, S., J. F. Engeln, and D. A. Wiens (1982), Subduction seismicity and tectonics in the lesser Antilles arc, J. Geophys. Res., 87, 8642-8664.

Sykes, L. R., and M. Ewing (1965), The seismicity of the Caribbean region, J. Geophys. Res., 70(20), 5065-5074.

Toda, S., R. S. Stein, and T. Sagiya (2002), Evidence from the AD 2000 Izu Islands earthquake swarm that stressing rate governs seismicity, Nature, 419, 58-61.

Tomblin, J. F., and W. P. Aspinall (1975), Reconnaissance report of the Antigua, West Indies, Earthquake of October 8, 1974, Bull. Seismol. Soc. Am., 65(6), 1553-1573.

Villemant, B., G. Hammouya, A. Michel, M. P. Semet, J. C. Komorowski, G. Boudon, and J. L. Cheminée (2005), The memory of volcanic waters: Shallow magma degassing revealed by halogen monitoring in therma springs of La Soufrière volcano(Guadeloupe, Lesser Antilles), Earth Planet. Sci. Lett., 237, 710-728.

Walter, T. R., and F. Amelung (2007), Volcanic eruptions following $M \geq 9$ megathrust earthquakes: Implications for the Sumatra-Andaman volcanoes, Geology, 35(6), 539-542.
Watt, S. F. L., D. M. Pyle, and T. A. Mather (2009), The inluence of great earthquakes on volcanic eruption rate along the Chilean subduction zone, Earth Planet. Sci. Lett., 277, 399-407.

Wells, D. L., and K. J. Coppersmith (1994), New empirical relationships among magnitude, rupture length, rupture width, rupture area, and surface displacement, Bull. Seismol. Soc. Am., 84(4), 974-1002.

Westbrook, G. K., J. W. Ladd, P. Buhl, N. Bangs, and G. J. Tiley (1988), Cross section of an accretionary wedge: Barbados Ridge complex, Geology, 16, 631-635.

Willmore, P. R. (1952), The earthquake series in St. Kitts-Nevis, 1950-51, Nature, 169, 770-772.

Young, S. R., R. P. Hoblitt, A. L. Smith, J. D. I. Devine, G. Wadge, and J. B. Shepherd (1996), Dating of explosive volcanic eruptions associated with dome growth at the Soufriere Hills volcano Montserrat, West Indies, paper presented at Second Caribbean Conference on Natural Hazards and Hazard Management, Univ. of the West Indies, Kingston, Jamaica.

F. Beauducel and N. Feuillet, Institut de Physique du Globe de Paris, UMR 7154 CNRS, Sorbonne Paris Cité, 1 rue Jussieu, F-75238 Paris CEDEX 05, France. (feuillet@ipgp.fr)

P. Tapponnier, Earth Observatory of Singapore, Nanyang Technological University, 50 Nanyang Avenue, 639798 Singapore. 